\title{
Psychometric Properties of the Berger HIV Stigma Scale: A Systematic Review
}

\author{
Stanley W. Wanjala ${ }^{1,2, *}$, Ezra K. Too ${ }^{3}\left(\mathbb{D}\right.$, Stanley Luchters ${ }^{1,3,4, *}$ and Amina Abubakar $3,5,6,7$ \\ 1 Department of Public Health and Primary Care, Campus UZ-Ghent, Ghent University, 9000 Ghent, Belgium \\ 2 Department of Social Sciences, Pwani University, Kilifi P.O. Box 195-80108, Kenya \\ 3 Institute for Human Development, Aga Khan University, Nairobi P.O. Box 30270-00100, Kenya; \\ ezra.too@aku.edu (E.K.T.); amina.abubakar@aku.edu (A.A.) \\ 4 Department of Epidemiology and Preventive Medicine, Monash University, Melbourne, VIC 3004, Australia \\ 5 Department of Public Health, Pwani University, Kilifi P.O. Box 195-80108, Kenya \\ 6 Department of Psychiatry, University of Oxford, Oxford OX3 7JX, UK \\ 7 Neuroassessment Group, KEMRI/Wellcome Trust Research Programme, Centre for Geographic Medicine \\ Research (Coast), Kilifi P.O. Box 230-80108, Kenya \\ * Correspondence: stanley.wanjala@ugent.be (S.W.W.); stanley.luchters@ugent.be (S.L.)
}

Citation: Wanjala, S.W.; Too, E.K.;

Luchters, S.; Abubakar, A.

Psychometric Properties of the Berger HIV Stigma Scale: A Systematic Review. Int. J. Environ. Res. Public Health 2021, 18, 13074. https:// doi.org/10.3390/ijerph182413074

Academic Editor: Paul B. Tchounwou

Received: 11 November 2021

Accepted: 8 December 2021

Published: 11 December 2021

Publisher's Note: MDPI stays neutral with regard to jurisdictional claims in published maps and institutional affiliations.

Copyright: (c) 2021 by the authors. Licensee MDPI, Basel, Switzerland. This article is an open access article distributed under the terms and conditions of the Creative Commons Attribution (CC BY) license (https:/ / creativecommons.org/licenses/by/ $4.0 /)$.

\begin{abstract}
Addressing HIV-related stigma requires the use of psychometrically sound measures. However, despite the Berger HIV stigma scale (HSS) being among the most widely used measures for assessing HIV-related stigma, no study has systematically summarised its psychometric properties. This review investigated the psychometric properties of the HSS. A systematic review of articles published between 2001 and August 2021 was undertaken (CRD42020220305) following the Preferred Reporting Items for Systematic Reviews and Meta-Analyses (PRISMA) guidelines. Additionally, we searched the grey literature and screened the reference lists of the included studies. Of the total 1241 studies that were screened, 166 were included in the review, of which 24 were development and/or validation studies. The rest were observational or experimental studies. All the studies except two reported some aspect of the scale's reliability. The reported internal consistency ranged from acceptable to excellent (Cronbach's alpha $\geq 0.70$ ) in 93.2\% of the studies. Only eight studies reported test-retest reliability, and the reported reliability was adequate, except for one study. Only 36 studies assessed and established the HSS's validity. The HSS appears to be a reliable and valid measure of HIV-related stigma. However, the validity evidence came from only 36 studies, most of which were conducted in North America and Europe. Consequently, more validation work is necessary for more precise insights.
\end{abstract}

Keywords: HIV/AIDS; psychometrics; stigma; HIV stigma scale

\section{Introduction}

The HIV / AIDS pandemic continues to be a major public health burden, affecting millions of people globally, with significant morbidity and mortality being reported. According to UNAIDS, approximately 37.7 million people were living with HIV / AIDS globally in 2020 [1]. Furthermore, there were approximately 680,000 HIV / AIDS-related deaths across the globe in 2020 [1]. This puts HIV/AIDS among the top 20 leading causes of death globally [2].

HIV-related stigma remains a significant impediment to the eradication of the HIV/AIDS pandemic. Across the globe, HIV-related stigma has been a contributing factor in delays in HIV testing [3,4] and engagement with HIV care [5]. Moreover, among people living with HIV (PLWH), it has had a role in suboptimal adherence to antiretroviral therapy (ART) [6] as well as disengagement from HIV care [7,8]. This has led to poor outcomes such as non-viral suppression [9] and faster infection progression [10]. Furthermore, HIV-related stigma has been associated with negative consequences that may further impede progress 
towards eradicating the pandemic, such as non-disclosure of HIV-positive status [11] and poor mental health functioning [9].

To adequately address HIV-related stigma, it needs to be measured using appropriate measurement tools [12]. Several tools have been developed for this purpose. These include the Internalized AIDS-related Stigma Scale [13], the Stigma and Social Impact Scale [14], the T.B. and HIV / AIDS Stigma Scale [15], the HIV Stigma Scale developed by Sowell and colleagues [16], the HIV Stigma Scales developed by Visser and colleagues [12], the HIV / AIDS Stigma Instrument [17], the Stigma mechanisms of the HIV stigma framework [18], the Internalized HIV Stigma Measure [19], and Berger's HIV Stigma Scale (HSS) [20], among others. To quantify the burden of HIV-related stigma adequately and accurately, these tools should be psychometrically sound across the diverse population of PLWH from different settings. Psychometric properties describe a scale's reliability and validity for use in a given population [21].

One of the most commonly used tools is the HSS developed by Berger and colleagues [20]. This tool is a 40-item measure that assesses perceived stigma in PLWH using a four-point Likert scale (strongly disagree $=1$, disagree $=2$, agree $=3$, strongly agree $=4$ ). The scale consists of four subscales that assess the various mechanisms through which PLWH experience stigma: personalised stigma, disclosure concerns, negative self-image, and concern with public attitudes. The personalised stigma subscale assesses the perceived consequences of other people knowing about an individual's HIV status. The disclosure concerns subscale assesses an individual's concerns or worries about disclosing their HIV status. The negative self-image subscale assesses an individual's negative feelings towards oneself due to HIV. Finally, the concern with public attitudes subscale assesses people's attitudes towards people with HIV.

During its development, the scale was shown to have excellent reliability and validity [20]. The scale, including its subscales and abbreviated versions, has since been validated and used widely among different HIV-positive populations in different settings, such as among the youth in Thailand [22], children in Sweden [23], men who have sex with men (MSM) in the United States [24], and women in Indonesia [25]. In these studies, it was observed that the scale was reliable and/or valid for use in these diverse sub-populations and settings.

Despite its extensive use and evidence of adequate psychometric properties across different settings, data on the scale's psychometric robustness has not been systematically summarised. For meaningful and accurate data that can inform the development and evaluation of HIV-stigma reduction interventions, researchers and related practitioners involved in HIV research and care who intend to use this scale require information on its psychometric robustness. Therefore, to address the above-mentioned gap, this study aims to systematically summarise the available data on the psychometric properties of the HSS in terms of reliability, content and face validity, construct validity, convergent and divergent validity, discriminant validity, and cross-cultural adaptation.

\section{Materials and Methods}

\subsection{Protocol and Registration}

This study's protocol was developed and registered in the International Prospective Register of Systematic Reviews (PROSPERO) under registration number CRD42020220305. This study followed the Preferred Reporting Items for Systematic Reviews and MetaAnalyses (PRISMA) guidelines [26].

\subsection{Search Strategy}

We performed a comprehensive bibliographic search on PubMed, Web of Sciencecore collection, PsycINFO, Scopus, and Embase (Excerpta Medica dataBASE) for relevant articles that were published from 2001 (when the scale was first published) to 24 August 2021 (when the last search was conducted). 
Our search structure included keywords such as "Stigma", "HIV infections", "Scale", and "Berger" combined by the Boolean operator "AND". Respective synonyms for these keywords were joined using the "OR" Boolean operator. Where applicable, Medical Subject Headings (MeSH) terms were used. The search strategy was adapted to fit the specifications of the different databases. Supplementary File S1 provides the search string used in the PubMed database.

The search was limited to articles published in the English language where a database could allow this filter. All the identified references were retrieved and uploaded to the EPPI Reviewer Web software (https:/ / eppi.ioe.ac.uk/EPPIReviewer-Web/Main, accessed on 21 September 2021) for data management. Additionally, we manually searched the reference lists of the included studies for additional relevant articles. We also searched the Open Grey database for potential grey literature that met our inclusion criteria.

\subsection{Eligibility Criteria \\ Inclusion and Exclusion Criteria}

To be included in the review, studies had to fulfil pre-determined inclusion and exclusion criteria. We included studies where the HSS (including abbreviated versions and subscales) was being developed and/or validated for use among PLWH or in the HIV-negative but affected population. We also included any studies (observational or experimental) that used any version of the HSS to assess HIV-related stigma and reported a psychometric measure of reliability and/or validity.

We excluded studies that used the HSS but did not report psychometric properties. We also excluded studies that used the HSS and reported the psychometric properties of the original scale or an earlier version of the scale. Studies that adapted the HSS for use in a population other than PLWH or HIV-affected participants were excluded. Studies that constructed scales using a mix of items from the HSS and other scales were also excluded. Studies published in languages other than English, qualitative studies, reviews, and studies for which the full text could not be found were all excluded. For duplicate reports from the same project, only the main and more comprehensive paper was considered.

\subsection{Screening of Articles by Inclusion and Exclusion Criteria}

For potential inclusion, all the identified articles from the database search were independently screened by two reviewers (S.W.W. and E.K.T.) in two steps: (i) by title and abstract and (ii) by full text. The reviewers held a meeting at the end of every step to resolve disagreements. Disagreements between the reviewers were consistently low and were resolved through consensus.

\subsection{Data Extraction}

Data extraction was conducted in the EPPI-Reviewer Web software by S.W.W. and E.K.T., who shared the included studies equally. The following information was extracted from the included studies: (i) article details- the name of first author, title, and year of publication; (ii) study information-country, study design, study setting, sampling method, and source of the sample; (iii) sample characteristics - the population involved, sample size, age (mean, median, or range), and sex (proportion of females); (iv) characteristics of the scale used-version of the scale used, the number of items in the scale, and mode of administration; (v) outcome- the reported psychometric properties of the scales used.

\subsection{Quality Assessment}

Two reviewers (S.W.W. and E.K.T.) independently assessed the quality of the included studies using the COnsensus-based Standards for the selection of health Measurement INstruments (COSMIN) checklist [27-29]. The two reviewers then resolved any disagreements in the quality rating through consensus. The COSMIN checklist contains standards (in terms of design requirements and preferred statistical methods) that assess the methodological quality of studies on measurement properties. The checklist contains boxes that 
contain the quality standards for each specific measurement property. The quality of each included study is evaluated by rating the quality standards of individual measurement properties on a four-point rating scale (inadequate, doubtful, adequate, very good) [30]. The overall rating of each study's quality is determined by taking the lowest rating of any standard in a box ("worse score counts" principle) [30].

In this review, we only assessed the quality of the development and/or validation studies. Since the primary aim of the included observational or experimental studies was not scale development and / or validation, they inadvertently did not provide standards that would enable quality assessment using the COSMIN checklist. Therefore, we anticipated that these studies would be rated poorly even though they may be of good quality.

\subsection{Data Analysis}

The included studies were heterogeneous in terms of the versions of the scale used and the sup-populations involved. Therefore, we summarised the data narratively by the reported psychometric properties. We categorised the countries where the included studies were conducted into their respective continents and used descriptive statistics (frequencies and percentages) to summarise their distribution. Descriptive statistics were also used to summarise the years of publication, the versions of the scale used, the populations involved, and the study types.

\section{Results}

\subsection{Results of Database Search}

The initial electronic search yielded 1241 records from the different databases (Embase, $n=94 ;$ Pubmed, $n=87$; PsycInfo, $n=162$; Scopus, $n=845$ and Web of Science, $n=53$ ). A search of the reference lists of the included articles yielded 14 additional articles. We also searched the Open Grey database for grey literature but did not find any relevant articles. After removing duplicates and screening the articles by the eligibility criteria, 166 articles were included in the review $[6,20,22-25,31-190]$. Figure 1 shows the PRISMA flowchart for the systematic review process.

\subsection{General Characteristics of the Included Studies}

Supplementary Table S1 presents the characteristics of the 166 included articles in detail. In summary, the included studies were published between 2001 and 2021, with the majority $(91.6 \%, n=152)$ being published from 2010 onwards. Most of the included studies $(46.4 \%, n=77)$ were conducted in North America (Supplementary Table S1). The remaining studies were distributed across Asia $(22.9 \%, n=38)$, Africa $(14.5 \%, n=24)$, Europe $(6.6 \%, n=11)$, South America $(6.0 \%, n=10)$, and Oceania $(1.2 \%, n=2)$. Four studies $(2.4 \%)$ were multicountry studies that were conducted in either four [82], three [146], or two countries $[99,124]$. Figure 2 shows the map of the geographical distribution of these studies.

Twenty-four of the included studies $[20,22,23,39,40,45,63,69,70,91-93,95,97,107,111$, $118,121,144,146,147,171,178,184]$ were development and/or validation studies of the HSS and/or its abbreviated versions. The remaining studies were observational or experimental studies that used the HSS to assess HIV-related stigma in different contexts.

The included studies recruited a total of 68,933 participants, with individual sample sizes ranging from 14 in Rwanda [98] to 2987 in China [187]. The recruited participants included diverse samples of PLWH, including adolescents and young adults living with HIV in 12 studies [22,23,38,62,72,80,83,125,126,129,163,178], adolescent girls and young women living with HIV in four studies $[33,54,68,117]$, pregnant women living with HIV in one study [31], older women living with HIV in one study [151], older adults living with HIV in seven studies $[44,61,63,77,81,139,161]$, women living with HIV in 19 studies [25,42,50,57-59,89,90,110,123,135,136,138,141,157,158,168,169,179], men living with HIV in six studies $[46,75,78,108,153,159]$, MSM living with HIV in 15 studies $[24,53,79,85,86$, $102,104,116,124,142,148,160,171,174,182]$, female sex workers living with HIV in three studies $[51,99,190]$, transgender women living with HIV in two studies [34,101], inmates living 
with HIV in one study [114], injectable drug users in one study [39], sexually active PLWH in one study [74], and homeless PLWH in one study [177]. Four studies $[40,55,106,118]$ recruited HIV-affected participants and adapted the HSS to assess stigma-by-association in this population. The remaining studies $(n=88)$ recruited participants from the general population of PLWH.

In terms of the versions of the HSS used, 51 studies used or validated the full 40-item version of the scale (Supplementary Table S1). Three studies [22,69,91] validated the full scale and further developed an abbreviated version of the scale. The remaining studies ( $n=112)$ used study-specific abbreviated versions or subscales of the HSS to assess HIVrelated stigma across various contexts.

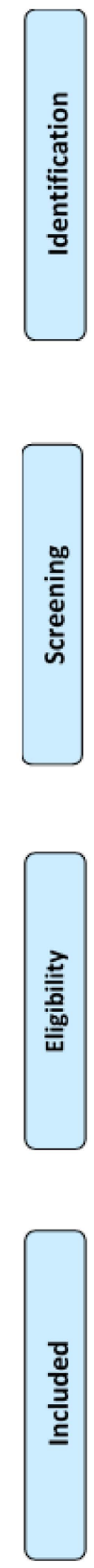

Records identified through database searching $(n=1,241)$
Additional records identified through other sources $(n=14)$
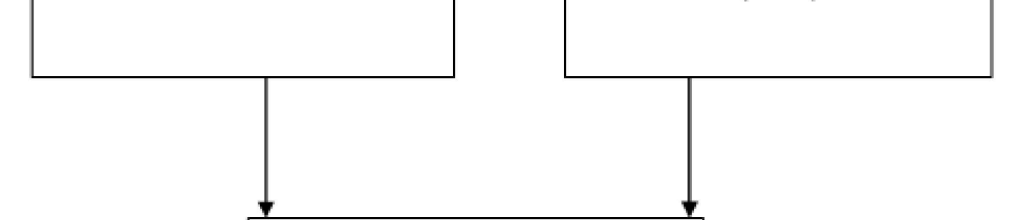

Records after duplicates removed

$(\mathrm{n}=976)$
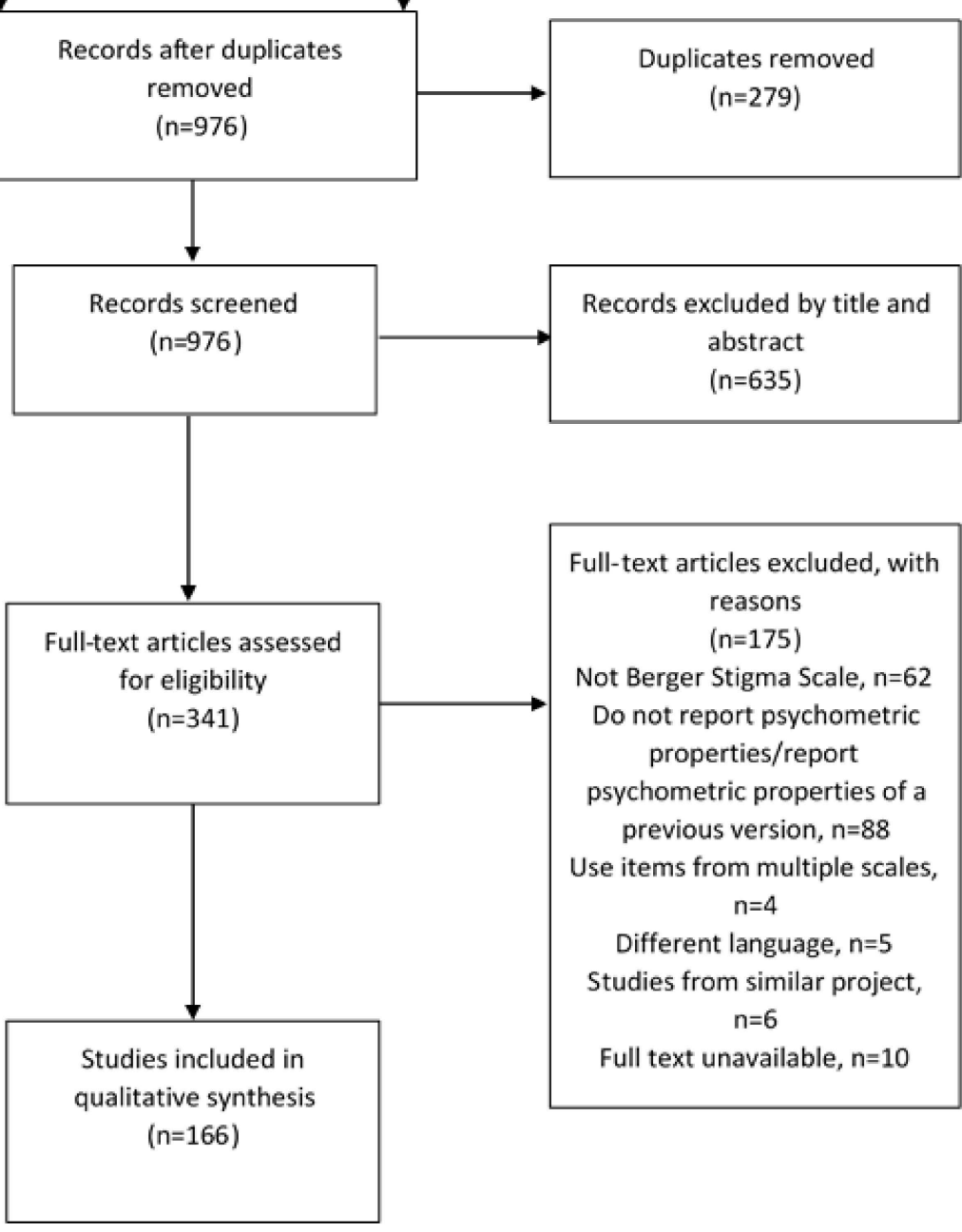

Full-text articles excluded, with reasons ( $n=175$ )

Not Berger Stigma Scale, $n=62$ Do not report psychometric properties/report psychometric properties of a previous version, $n=88$ Use items from multiple scales, $\mathrm{n}=4$

Different language, $n=5$ Studies from similar project, $\mathrm{n}=6$

Full text unavailable, $\mathrm{n}=10$

Figure 1. PRISMA flowchart for the systematic review process. 


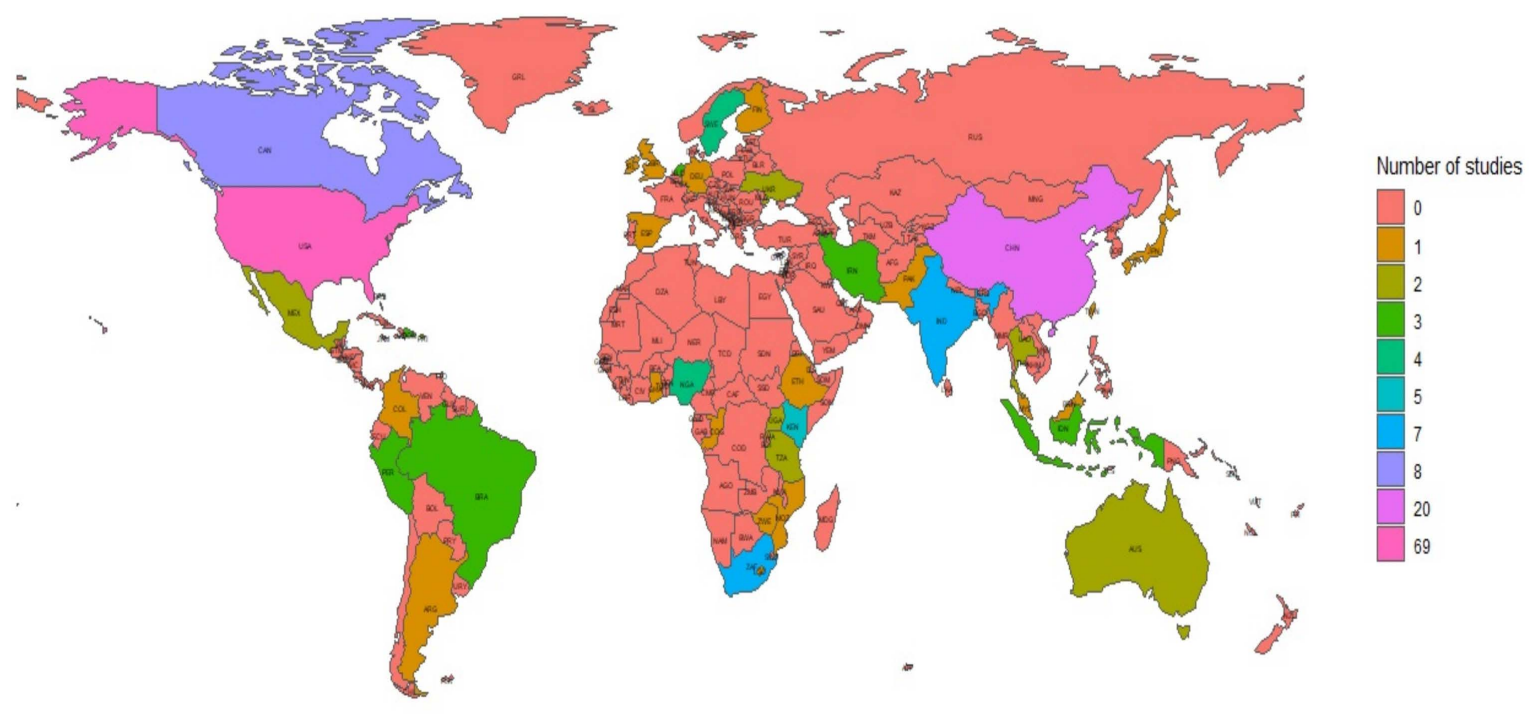

Figure 2. World map showing the geographic distribution of included studies.

\subsection{Reliability of the HSS}

Table 1 and Supplementary Table S2 present the reliability of the HSS as reported by the development and/or validation studies and observational or experimental studies, respectively.

In summary, all but two [144,146] of the included studies reported an aspect of reliability of the HSS.

\section{Internal Consistency and Test-Retest Reliability}

Of the 164 studies that reported an aspect of reliability, all the studies reported the internal consistency of the HSS, except one study [166], which only reported the testretest reliability of a 40-item version used in a US sample of PLWH. Of these, seven studies $[20,39,52,88,91,92,121]$ additionally reported the scale's test-retest reliability. In one study [39], split-half reliability was additionally assessed and reported to be adequate (0.93). No study reported the intra- or interrater reliability of the scale.

For internal consistency, all the studies, except a 4-item scale in one study [127] and some subscales in ten studies [23,52,68,69,91,111,170,172,176,189], reported Cronbach's alphas of above the recommended acceptable threshold of 0.70 [191]. Two studies [34,95] reported the internal consistency of the HSS using McDonald's omega instead of Cronbach's alpha and reported good reliability (Table 1 and Supplementary Table S2). In one study [111], Cronbach's alpha (0.83), ordinal alpha (0.88), and omega alpha (0.93) were reported as measures of internal consistency. For test-retest reliability, the intraclass correlations in all the studies were above the recommended cut-off score of 0.40 [191], except for the concern with public attitudes subscale in the 17-item HSS used in Puerto Rico, which reported an intraclass correlation coefficient of 0.27 [92].

\subsection{Validity of the HSS}

Table 1 and Supplementary Table S2 present the validity of the HSS as reported by the development and/or validation studies and observational or experimental studies, respectively, in detail. In total, 36 of the included studies assessed an aspect of the validity of the HSS (Table 1 and Supplementary Table S2). 
Table 1. Psychometric properties of the HSS as reported by the development and/or validation studies.

\begin{tabular}{|c|c|c|c|c|c|c|c|c|c|c|}
\hline \multirow[t]{2}{*}{$\begin{array}{l}\text { First Author } \\
\text { (Year) }\end{array}$} & \multirow[t]{2}{*}{ Scale Used } & \multicolumn{2}{|c|}{ Reliability } & \multicolumn{7}{|c|}{ Validity } \\
\hline & & $\begin{array}{c}\text { Internal } \\
\text { Consistency } \\
\text { (Cronbach's } \\
\text { Alpha unless } \\
\text { Otherwise Stated) }\end{array}$ & $\begin{array}{c}\text { Test-Retest } \\
\text { Reliability (icc) }\end{array}$ & Construct Validity & Convergent Validity & $\begin{array}{l}\text { Divergent } \\
\text { Validity }\end{array}$ & $\begin{array}{l}\text { Discriminant } \\
\text { Validity }\end{array}$ & Content Validity & Face Validity & $\begin{array}{l}\text { Cross-Cultural } \\
\text { Adaptation and/or } \\
\text { Validity }\end{array}$ \\
\hline $\begin{array}{l}\text { Berger et al., } \\
2001[20]\end{array}$ & $\begin{array}{l}\text { 40-item } \\
\text { scale }\end{array}$ & $\begin{array}{l}0.96 \text { for the overall } \\
\text { scale } \\
0.90-0.93 \text { for the } \\
\text { subscales }\end{array}$ & $\begin{array}{l}0.92 \text { for the } \\
\text { overall scale } \\
0.87-0.90 \text { for } \\
\text { subscales }\end{array}$ & $\begin{array}{l}\text { EFA revealed a 4-factor } \\
\text { structure that reflected } \\
\text { the dimensions of } \\
\text { perceived HIV-related } \\
\text { stigma and explained } \\
46 \% \text { of the } \\
\text { total variance } \\
\text { The four factors } \\
\text { intercorrelated and } \\
\text { represented one } \\
\text { higher-order factor }\end{array}$ & $\begin{array}{l}\text { Expected correlation }(\mathrm{r}) \text { between } \\
\text { the overall scale, including } \\
\text { subscales, and self-esteem } \\
(-0.35--0.68) \text {, depression } \\
(0.41-0.63) \text {, social support } \\
(-0.38--0.54) \text {, subjective social } \\
\text { integration }(-0.50--0.65) \text {, and } \\
\text { social conflict }(0.40-0.59) \\
p<0.001 \text { for all correlations }\end{array}$ & NR & NR & $\begin{array}{l}\text { Experts judged all } \\
\text { the items in the } \\
\text { scale to be clear } \\
\text { and relevant }\end{array}$ & NR & NR \\
\hline $\begin{array}{l}\text { Bint-E-Saif \& } \\
\text { Shahzad, } \\
2020 \text { [39] }\end{array}$ & $\begin{array}{l}\text { 40-item } \\
\text { scale }\end{array}$ & $\begin{array}{l}0.94 \text { for the } \\
\text { overall scale } \\
0.81-0.91 \text { for } \\
\text { the subscales } \\
\text { Split-half } \\
\text { reliability of } 0.93\end{array}$ & $\begin{array}{l}0.96 \text { for the } \\
\text { overall scale } \\
0.92-0.95 \text { for the } \\
\text { subscales }\end{array}$ & NR & $\begin{array}{l}\text { Significant positive correlation }(\mathrm{r}) \\
\text { with depression }(0.45-0.66, p<0.01) \\
\text { Significant negative correlation }(\mathrm{r}) \\
\text { with self-esteem. }(-0.36--0.55 \\
p<0.01)\end{array}$ & NR & NR & NR & NR & $\begin{array}{l}\text { Scale translated to } \\
\text { Urdu, compared } \\
\text { and evaluated } \\
\text { with the original } \\
\text { version and finally } \\
\text { back-translated } \\
\text { to English }\end{array}$ \\
\hline
\end{tabular}


Table 1. Cont.

\begin{tabular}{|c|c|c|c|c|c|c|c|c|c|c|}
\hline \multirow[t]{2}{*}{$\begin{array}{l}\text { First Author } \\
\text { (Year) }\end{array}$} & \multirow[t]{2}{*}{ Scale Used } & \multicolumn{2}{|c|}{ Reliability } & \multicolumn{7}{|c|}{ Validity } \\
\hline & & $\begin{array}{c}\text { Internal } \\
\text { Consistency } \\
\text { (Cronbach's } \\
\text { Alpha unless } \\
\text { Otherwise Stated) }\end{array}$ & $\begin{array}{c}\text { Test-Retest } \\
\text { Reliability (icc) }\end{array}$ & Construct Validity & Convergent Validity & $\begin{array}{c}\text { Divergent } \\
\text { Validity }\end{array}$ & $\begin{array}{l}\text { Discriminant } \\
\text { Validity }\end{array}$ & Content Validity & Face Validity & $\begin{array}{l}\text { Cross-Cultural } \\
\text { Adaptation and/or } \\
\text { Validity }\end{array}$ \\
\hline $\begin{array}{l}\text { Bunn et al., } \\
2007 \text { [45] }\end{array}$ & $\begin{array}{l}\text { 32-item } \\
\text { scale }\end{array}$ & $\begin{array}{l}0.95 \text { for the } \\
\text { overall scale } \\
0.90-0.97 \text { for the } \\
\text { subscales }\end{array}$ & NR & $\begin{array}{l}\text { CFA retained the } \\
4 \text {-factor structure of the } \\
\text { original scale with } \\
\text { good model fit }\left(\chi^{2} \text { test }\right. \\
p<0.01 ; \text { CFI }=0.908 ; \\
\text { RMSEA }=0.072)\end{array}$ & $\begin{array}{l}\text { Expected correlation }(\mathrm{r}) \text { between } \\
\text { the overall scale, including } \\
\text { subscales, and self-esteem } \\
(-0.14--0.56) \text {, stigma } \\
\text { consciousness }(0.38-0.62) \text {, } \\
\text { discrimination }(0.17-0.75) \text {, and fear } \\
\text { of discovery }(0.43-0.75) \\
p<0.005 \text { for all correlations except } \\
\text { for disclosure concerns subscale } \\
\text { with self-esteem }\end{array}$ & NR & NR & NR & NR & NR \\
\hline $\begin{array}{l}\text { Emlet et al., } \\
2007 \text { [63] }\end{array}$ & $\begin{array}{l}40 \text {-item } \\
\text { Scale }\end{array}$ & $\begin{array}{l}0.96 \text { for the } \\
\text { overall scale } \\
0.92-0.96 \text { for the } \\
\text { subscales }\end{array}$ & NR & NR & $\begin{array}{l}\text { Expected correlation }(\mathrm{r}) \text { between } \\
\text { the overall scale, including } \\
\text { subscales, and depression } \\
(0.34-0.71) \\
p<0.001 \text { or }<0.01 \text { for all } \\
\text { correlations except for disclosure } \\
\text { concerns subscale with depression }\end{array}$ & NR & NR & $\begin{array}{l}\text { Majority of } \\
\text { participants felt } \\
\text { the scale was valid } \\
\text { and represented } \\
\text { older people }\end{array}$ & NR & NR \\
\hline
\end{tabular}


Table 1. Cont.

\begin{tabular}{|c|c|c|c|c|c|c|c|c|c|c|}
\hline \multirow[t]{2}{*}{$\begin{array}{l}\text { First Author } \\
\text { (Year) }\end{array}$} & \multirow[t]{2}{*}{ Scale Used } & \multicolumn{2}{|c|}{ Reliability } & \multicolumn{7}{|c|}{ Validity } \\
\hline & & $\begin{array}{c}\text { Internal } \\
\text { Consistency } \\
\text { (Cronbach's } \\
\text { Alpha unless } \\
\text { Otherwise Stated) }\end{array}$ & $\begin{array}{c}\text { Test-Retest } \\
\text { Reliability (icc) }\end{array}$ & Construct Validity & Convergent Validity & $\begin{array}{c}\text { Divergent } \\
\text { Validity }\end{array}$ & $\begin{array}{l}\text { Discriminant } \\
\text { Validity }\end{array}$ & Content Validity & Face Validity & $\begin{array}{l}\text { Cross-Cultural } \\
\text { Adaptation and/or } \\
\text { Validity }\end{array}$ \\
\hline $\begin{array}{l}\text { Fuster- } \\
\text { RuizdeApodaca } \\
\text { et al., } 2015 \\
\text { [70] }\end{array}$ & $\begin{array}{l}\text { 30-item } \\
\text { scale }\end{array}$ & $\begin{array}{l}0.88 \text { for the } \\
\text { overall scale. } \\
0.75-0.89 \text { for } \\
\text { the subscales. }\end{array}$ & NR & $\begin{array}{l}\text { First-order CFA retained } \\
\text { the } 4 \text {-factor structure } \\
\text { with good model fit } \\
\text { (RMSEA =0.054; } \\
\text { GFI =0.96; CFI = } 0.98 ; \\
\chi^{2} \text { test } p=0.001 \text { ) } \\
\text { Second-order CFA } \\
\text { yielded a higher order } \\
\text { 2-factor structure with } \\
\text { a better model fit } \\
\text { (RMSEA =0.051; } \\
\text { GFI }=0.96 ; C F I=0.98 \text { ) }\end{array}$ & $\begin{array}{l}\text { Expected correlation }(\mathrm{r}) \text { between } \\
\text { the overall scale, including } \\
\text { subscales, and social support } \\
(-0.13--0.36) \text {, life satisfaction } \\
(-0.18--0.34) \text {, physical and } \\
\text { psychological well-being } \\
(-0.16--0.30) \text {, self-efficacy to cope } \\
\text { with stigma }(-0.30--0.54) \text {, and } \\
\text { degree of HIV status disclosure } \\
(-0.07--0.54) \\
p<0.01 \text { for all correlations }\end{array}$ & NR & $\begin{array}{l}\text { Perceived } \\
\text { external stigma } \\
\text { scores were } \\
\text { significantly } \\
\text { higher in those } \\
\text { with a history of } \\
\text { AIDS-related } \\
\text { opportunistic } \\
\text { infection } \\
\text { compared to } \\
\text { those without } \\
(p=0.003)\end{array}$ & $\begin{array}{l}\text { Seven experts } \\
\text { conducted content } \\
\text { analysis of the } \\
\text { interviews and } \\
\text { coded them into } \\
\text { relevant concepts } \\
\text { and topics. } \\
\text { Inter-rater } \\
\text { reliability of the } \\
\text { codings yielded } \\
\text { substantial } \\
\text { reliability ( } K=0.77 \text {, } \\
S D=0.10 \text { ) }\end{array}$ & $\begin{array}{l}\text { A pilot sample } \\
\text { of PLWH } \\
\text { reviewed the } \\
\text { final version of } \\
\text { the scale to } \\
\text { ensure face } \\
\text { validity }\end{array}$ & $\begin{array}{l}\text { Scale translated } \\
\text { independently to } \\
\text { Spanish } \\
\text { Research team } \\
\text { assessed the } \\
\text { translations and } \\
\text { reached a } \\
\text { consensus on the } \\
\text { final items } \\
\text { Scale then adapted } \\
\text { to the Spanish } \\
\text { context following } \\
\text { interviews with } \\
\text { participants and } \\
\text { expert review }\end{array}$ \\
\hline $\begin{array}{l}\text { Jeyaseelan } \\
\text { et al., } 2013 \\
\text { [91] }\end{array}$ & $\begin{array}{l}40 \text { and } \\
25 \text {-item } \\
\text { scales }\end{array}$ & $\begin{array}{l}0.91 \text { and } 0.88 \text { for } \\
\text { the overall } 40 \text { and } \\
25 \text {-item scales, } \\
\text { respectively. } \\
0.62-0.89 \text { for the } \\
\text { subscales in the } \\
40 \text {-item scale. } \\
0.19-0.88 \text { for the } \\
\text { subscales in the } \\
25 \text {-item scale. }\end{array}$ & $\begin{array}{l}0.89 \text { for the } \\
\text { overall } 40 \text {-item } \\
\text { scale. } \\
0.62-0.85 \text { for the } \\
\text { subscales in the } \\
40 \text {-item scale. } \\
\text { NR for the } \\
25 \text {-item scale. }\end{array}$ & $\begin{array}{l}\text { CFA of the } 40 \text {-item } \\
\text { scale retained the } \\
\text { 4-factor structure but } \\
\text { with poor model fit } \\
\text { (RMSEA }=0.31 ; \\
\text { CFI }=0.95 ; \text { CF }<0.80 \\
\text { for } 3 \text { subscales) } \\
\text { EFA and CFA of the } \\
\text { 25-item scale retained } \\
\text { the } 4 \text {-factor structure } \\
\text { with improved model } \\
\text { fit (RMSEA = } 0.07 \text {; } \\
\text { CFI = } 0.99 \text { for the } \\
\text { overall } 25 \text {-item scale; } \\
\text { RMSEA of } 0.00-0.08 \\
\text { and CFI of } 0.94-1.0 \text { for } \\
\text { the subscales) }\end{array}$ & $\begin{array}{l}\text { Stigma scores in the } 40 \text {-item scale } \\
\text { and its subscales were significantly } \\
\text { higher in PLWH with major } \\
\text { depression compared to those } \\
\text { without }(p<0.01) \\
\text { Stigma scores in the } 25 \text {-item scale } \\
\text { and its subscales were significantly } \\
\text { higher in PLWH with major } \\
\text { depression compared to those } \\
\text { without }(p<0.05)\end{array}$ & NR & NR & $\begin{array}{l}\text { A pilot sample of } \\
\text { participants had } \\
\text { concerns about the } \\
\text { repetitiveness of } \\
\text { questions, } \\
\text { comprehensibility } \\
\text { of the rating scale, } \\
\text { and the wording } \\
\text { of items in first } \\
\text { person } \\
\text { Items were } \\
\text { subsequently } \\
\text { modified } \\
\text { following this } \\
\text { feedback }\end{array}$ & $\begin{array}{l}\text { Overall, an } \\
\text { expert panel } \\
\text { rated the scale as } \\
\text { meaningful and } \\
\text { relevant to the } \\
\text { Indian context } \\
\text { Few raised } \\
\text { concerns about } \\
\text { the } \\
\text { repetitiveness of } \\
\text { the scale }\end{array}$ & $\begin{array}{l}\text { Scale translated to } \\
\text { Tamil then } \\
\text { back-translated to } \\
\text { English. } \\
\text { Misinterpreted } \\
\text { concepts clarified } \\
\text { using the } \\
\text { respondents' } \\
\text { feedback during } \\
\text { this process. }\end{array}$ \\
\hline
\end{tabular}


Table 1. Cont.

\begin{tabular}{|c|c|c|c|c|c|c|c|c|c|c|}
\hline \multirow[t]{2}{*}{$\begin{array}{c}\text { First Author } \\
\text { (Year) }\end{array}$} & \multirow[t]{2}{*}{ Scale Used } & \multicolumn{2}{|c|}{ Reliability } & \multicolumn{7}{|c|}{ Validity } \\
\hline & & $\begin{array}{c}\text { Internal } \\
\text { Consistency } \\
\text { (Cronbach's } \\
\text { Alpha unless } \\
\text { Otherwise Stated) }\end{array}$ & $\begin{array}{c}\text { Test-Retest } \\
\text { Reliability (icc) }\end{array}$ & Construct Validity & Convergent Validity & $\begin{array}{l}\text { Divergent } \\
\text { Validity }\end{array}$ & $\begin{array}{l}\text { Discriminant } \\
\text { Validity }\end{array}$ & Content Validity & Face Validity & $\begin{array}{l}\text { Cross-Cultural } \\
\text { Adaptation and/or } \\
\text { Validity }\end{array}$ \\
\hline $\begin{array}{l}\text { Jimenez et al., } \\
2010 \text { [92] }\end{array}$ & $\begin{array}{l}17 \text {-item } \\
\text { scale }\end{array}$ & $\begin{array}{l}0.91 \text { for the } \\
\text { overall scale. } \\
0.77-0.88 \text { for the } \\
\text { subscales. }\end{array}$ & $\begin{array}{l}0.68 \text { for the } \\
\text { overall scale. } \\
0.27-0.73 \text { for } \\
\text { the subscales. }\end{array}$ & $\begin{array}{l}\text { Factor analysis } \\
\text { replicated the } 4 \text {-factor } \\
\text { structure of the } \\
\text { original scale with } \\
\text { factor loadings }>40\end{array}$ & $\begin{array}{l}\text { Expected correlation }(\mathrm{r}) \text { between } \\
\text { the overall scale, including } \\
\text { subscales, and sexual abuse } \\
(0.15-0.29) \text {, depression }(0.10-0.44) \text {, } \\
\text { and stigmatization }(0.47-0.79) \\
p<0.05 \text { or }<0.01 \text { for all } \\
\text { correlations except for disclosure } \\
\text { concerns subscale with depression } \\
\text { and sexual abuse }\end{array}$ & NR & NR & NR & NR & $\begin{array}{l}\text { Scale translated to } \\
\text { Spanish and } \\
\text { back-translated to } \\
\text { English. } \\
\text { Scale was then } \\
\text { adapted to the } \\
\text { Spanish population } \\
\text { by incorporating } \\
\text { native terms and } \\
\text { expressions } \\
\text { generated from } \\
\text { FGDs. }\end{array}$ \\
\hline $\begin{array}{l}\text { Johnson et al., } \\
2016 \text { [93] }\end{array}$ & $\begin{array}{l}\text { 10-item } \\
\text { scale }\end{array}$ & $\begin{array}{l}0.78 \text { and } 0.74 \text { for } \\
\text { the subscales }\end{array}$ & NR & $\begin{array}{l}\text { EFA yielded a 2-factor } \\
\text { structure accounting for } \\
52 \% \text { of the total variance } \\
\text { with Eigen values }>1 ; \\
\text { confirmed by CFA with } \\
\text { excellent model fit } \\
\text { statistics: } \chi^{2}(34, \\
n=120)=45.06, p=0.10, \\
n s, \chi^{2} / d f=1.33, \\
\text { CFI }=0.96, \\
\text { RMSEA }=0.055\end{array}$ & $\begin{array}{l}\text { Significant positive correlations } \\
\text { with depression (both subscales; } \\
0.38 \text { and } 0.30, p<0.01) \text { ), HIV } \\
\text { symptoms (both subscales; } 0.39 \\
\text { and } 0.27, p<0.01 \text { ) } \\
\text { Significant negative correlations } \\
\text { with spirituality } / \text { religiousness } \\
\text { (social stigma subscale; } 0.23 \text {, } \\
p<0.05 \text { ), and CD4 count } \\
\text { (self-stigma subscale; } 0.32, p<0.01 \text { ) }\end{array}$ & NR & NR & NR & NR & NR \\
\hline $\begin{array}{l}\text { Kagiura et al., } \\
2020 \text { [95] }\end{array}$ & 9-item scale & $\begin{array}{l}\text { McDonald's } \\
\text { Omega of } 0.89 \text { for } \\
\text { the overall scale } \\
0.83 \text { and } 0.87 \text { for } \\
\text { the two subscales }\end{array}$ & NR & $\begin{array}{l}\text { CFA of the 4-factor } \\
\text { structure confirmed the } \\
\text { original structure with } \\
\text { sufficient model fit } \\
\text { statistics but with } \\
\text { insufficient reliability } \\
\text { (two subscales with } \\
\text { McDonald's } \\
\text { Omega }<0.70 \text { ) } \\
\text { EFA was then } \\
\text { conducted, which } \\
\text { yielded a 2-factor } \\
\text { structure with factor } \\
\text { loadings }>0.40 \text { and } \\
\text { sufficient reliability }\end{array}$ & $\begin{array}{l}\text { Significant positive correlation with } \\
\text { depression }(0.37-0.45, p<0.001) \\
\text { Significant negative correlation with } \\
\text { self-esteem. }(-0.34--0.51, p<0.001)\end{array}$ & NR & NR & NR & NR & $\begin{array}{l}\text { Scale translated to } \\
\text { Japanese and } \\
\text { back-translated } \\
\text { to English } \\
\text { Both versions were } \\
\text { then compared, } \\
\text { and discrepancies } \\
\text { resolved } \\
\text { Experts then } \\
\text { agreed that all but } \\
\text { three items had } \\
\text { satisfactory } \\
\text { Japanese } \\
\text { descriptions; these } \\
\text { items were } \\
\text { subsequently } \\
\text { modified to fit the } \\
\text { Japanese context. }\end{array}$ \\
\hline
\end{tabular}


Table 1. Cont.

\begin{tabular}{|c|c|c|c|c|c|c|c|c|c|c|}
\hline \multirow[t]{2}{*}{$\begin{array}{l}\text { First Author } \\
\text { (Year) }\end{array}$} & \multirow[t]{2}{*}{ Scale Used } & \multicolumn{2}{|c|}{ Reliability } & \multicolumn{7}{|c|}{ Validity } \\
\hline & & $\begin{array}{c}\text { Internal } \\
\text { Consistency } \\
\text { (Cronbach's } \\
\text { Alpha unless } \\
\text { Otherwise Stated) }\end{array}$ & $\begin{array}{c}\text { Test-Retest } \\
\text { Reliability (icc) }\end{array}$ & Construct Validity & Convergent Validity & $\begin{array}{l}\text { Divergent } \\
\text { Validity }\end{array}$ & $\begin{array}{l}\text { Discriminant } \\
\text { Validity }\end{array}$ & Content Validity & Face Validity & $\begin{array}{l}\text { Cross-Cultural } \\
\text { Adaptation and/or } \\
\text { Validity }\end{array}$ \\
\hline $\begin{array}{l}\text { Kamitani } \\
\text { et al., } 2018 \\
\text { [97] }\end{array}$ & $\begin{array}{l}10 \text { - and } \\
13 \text {-item } \\
\text { scales }\end{array}$ & $\begin{array}{l}0.90 \text { and } 0.92 \text { for } \\
\text { the overall } 10 \text { and } \\
13 \text {-item scales, } \\
\text { respectively. } \\
0.80-0.87 \text { for the } \\
\text { subscales in the } \\
10-\text { item scale. } \\
0.80-0.87 \text { for the } \\
\text { subscales in the } \\
13 \text {-item scale. }\end{array}$ & NR & $\begin{array}{l}\text { EFA yielded a } 4 \text {-factor } \\
\text { structure for the } \\
10 \text {-item scale and a } \\
3 \text {-factor structure for } \\
\text { the } 13 \text {-item scale. } \\
\text { Factor loadings of } \\
0.57-0.85 \text { for the } \\
13 \text {-item scale. } \\
\text { Factor loadings of } \\
0.70-0.86 \text { for the } \\
10 \text {-item scale. }\end{array}$ & $\begin{array}{l}\text { Expected correlation }(\mathrm{r}) \text { between } \\
\text { the } 13 \text {-item scale and self-reported } \\
\text { health }(-0.36, p=0.003) \text { and } \\
\text { acculturation }(-0.33, p=0.006)\end{array}$ & $\begin{array}{l}\text { No association } \\
\text { between the } \\
\text { scale and } \\
\text { education level } \\
(B=-0.28 \\
p=0.93)\end{array}$ & NR & $\begin{array}{l}\text { Six experts agreed } \\
\text { that the 13-item } \\
\text { scale had good } \\
\text { content using the } \\
\text { content validity } \\
\text { index (score of } 1 \text { ). } \\
\text { Items were } \\
\text { modified based on } \\
\text { suggestions from } \\
\text { an initial FGD, } \\
\text { and participants } \\
\text { in a second FGD } \\
\text { approved the final } \\
\text { version to be } \\
\text { relevant. }\end{array}$ & NR & $\begin{array}{l}\text { Items were } \\
\text { adapted to the } \\
\text { Asian population } \\
\text { following in-depth } \\
\text { interviews with } \\
\text { participants and } \\
\text { reviews by } \\
\text { experts. }\end{array}$ \\
\hline $\begin{array}{l}\text { Lindberg } \\
\text { et al., 2014 } \\
\text { [107] }\end{array}$ & $\begin{array}{l}\text { 39-item } \\
\text { scale }\end{array}$ & $\begin{array}{l}0.96 \text { for the } \\
\text { overall scale. } \\
0.87-0.96 \text { for the } \\
\text { subscales. }\end{array}$ & NR & $\begin{array}{l}\text { The } 4 \text {-factor structure } \\
\text { similar to the original } \\
\text { scale was retained } \\
\text { on EFA. } \\
\text { The four factors } \\
\text { accounted for } 62.2 \% \text { of } \\
\text { the variance. }\end{array}$ & $\begin{array}{l}\text { Expected correlation }(\mathrm{r}) \text { between } \\
\text { the overall scale, including } \\
\text { subscales, and emotional } \\
\text { wellbeing }(-0.21--0.49 \text {, } \\
p<0.01 \text { or } 0.001)\end{array}$ & NR & NR & $\begin{array}{l}\text { A pilot sample } \\
\text { found the items to } \\
\text { be relevant and } \\
\text { comprehensive } \\
\text { through } \\
\text { think-aloud } \\
\text { interviews }\end{array}$ & NR & $\begin{array}{l}\text { Scale was } \\
\text { translated to } \\
\text { Swedish by three } \\
\text { translators, then } \\
\text { back-translated to } \\
\text { English by an } \\
\text { independent } \\
\text { translator. } \\
\text { Minor changes } \\
\text { were made to } \\
\text { ensure that no } \\
\text { meaning was lost } \\
\text { in translation. }\end{array}$ \\
\hline
\end{tabular}


Table 1. Cont.

\begin{tabular}{|c|c|c|c|c|c|c|c|c|c|c|}
\hline \multirow[t]{2}{*}{$\begin{array}{l}\text { First Author } \\
\text { (Year) }\end{array}$} & \multirow[t]{2}{*}{ Scale Used } & \multicolumn{2}{|c|}{ Reliability } & \multicolumn{7}{|c|}{ Validity } \\
\hline & & $\begin{array}{c}\text { Internal } \\
\text { Consistency } \\
\text { (Cronbach's } \\
\text { Alpha unless } \\
\text { Otherwise Stated) }\end{array}$ & $\begin{array}{c}\text { Test-Retest } \\
\text { Reliability (icc) }\end{array}$ & Construct Validity & Convergent Validity & $\begin{array}{c}\text { Divergent } \\
\text { Validity }\end{array}$ & $\begin{array}{l}\text { Discriminant } \\
\text { Validity }\end{array}$ & Content Validity & Face Validity & $\begin{array}{l}\text { Cross-Cultural } \\
\text { Adaptation and/or } \\
\text { Validity }\end{array}$ \\
\hline $\begin{array}{l}\text { Luz et al., } \\
2020 \text { [111] }\end{array}$ & $\begin{array}{l}\text { 12-item } \\
\text { scale }\end{array}$ & $\begin{array}{l}\text { Cronbach's alpha, } \\
\text { ordinal alpha and } \\
\text { omega of } 0.83,0.88 \\
\text { and } 0.93 \text { for the } \\
\text { overall scale } \\
\text { Cronbach's alpha } \\
\text { of } 0.69-0.87 \text { for the } \\
\text { subscales } \\
\text { Ordinal alpha of } \\
0.78-0.93 \text { for the } \\
\text { subscales } \\
\text { Omega of } \\
0.78-0.94 \text { for the } \\
\text { subscales }\end{array}$ & NR & $\begin{array}{l}\text { A 4-factor structure } \\
\text { showed good fit in all } \\
\text { samples [Grindr: } \chi^{2} \\
(48)=56.9, p=0.17, \text { CFI } \\
=0.995, \mathrm{TLI}=0.993, \\
\text { RMSEA }=0.040 \text {, SRMR } \\
=0.062 ; \text { social media: } \\
\chi^{2}(48)=63.4, p=0.07, \\
\text { CFI }=0.993 ; \text { Hornet } \\
\text { sample } \chi^{2}(54)=498.2, \\
p<0.01, \text { CFI }=0.980, \\
\text { TLI }=0.973, \text { RMSEA }= \\
0.071, \text { SRMR }=0.039]\end{array}$ & NR & NR & $\begin{array}{l}\text { As expected, } \\
\text { stigma scores } \\
\text { were } \\
\text { significantly } \\
\text { higher in those } \\
\text { who were not } \\
\text { on antiretroviral } \\
\text { treatment } \\
\text { compared to } \\
\text { those on } \\
\text { treatment for } \\
\text { the } \\
\text { personalized } \\
\text { stigma in the } \\
\text { Grindr sample } \\
\text { (p=0.02) } \\
\text { Participants } \\
\text { whom } \\
\text { self-reported } \\
\text { non-adherence } \\
\text { scored higher } \\
\text { than those } \\
\text { who were } \\
\text { adherent on } \\
\text { personalized } \\
\text { stigma for the } \\
3 \text { samples } \\
\text { ( } p=0.01-0.03) \\
\text { Among } \\
\text { participants } \\
\text { from the Hornet } \\
\text { sample, those } \\
\text { who were } \\
\text { nonadherent } \\
\text { scored higher } \\
\text { with regard to } \\
\text { concerns about } \\
\text { public attitudes } \\
\text { and negative } \\
\text { self-image } \\
(p<0.01)\end{array}$ & $\begin{array}{l}\text { Experts assessed } \\
\text { the relevance of } \\
\text { the items in the } \\
\text { scale then a pilot } \\
\text { sample of } \\
\text { participants } \\
\text { judged all items as } \\
\text { clear, with only } \\
\text { two items being } \\
\text { slightly modified } \\
\text { as needed } \\
\text { following their } \\
\text { feedback }\end{array}$ & NR & $\begin{array}{l}\text { - Scale translated } \\
\text { to Brazilian } \\
\text { Portuguese and } \\
\text { back-translated to } \\
\text { English, evaluated } \\
\text { by experts and } \\
\text { pilot-tested } \\
\text { Small DIF with } \\
\text { respect to sample } \\
\text { (based on the } \\
\text { platform that they } \\
\text { were recruited } \\
\text { from, i.e., Grindr, } \\
\text { Hornet, and social } \\
\text { media) was found } \\
\text { for one item }\end{array}$ \\
\hline
\end{tabular}


Table 1. Cont.

\begin{tabular}{|c|c|c|c|c|c|c|c|c|c|c|}
\hline \multirow[t]{2}{*}{$\begin{array}{l}\text { First Author } \\
\text { (Year) }\end{array}$} & \multirow[t]{2}{*}{ Scale Used } & \multicolumn{2}{|c|}{ Reliability } & \multicolumn{7}{|c|}{ Validity } \\
\hline & & $\begin{array}{c}\text { Internal } \\
\text { Consistency } \\
\text { (Cronbach's } \\
\text { Alpha unless } \\
\text { Otherwise Stated) }\end{array}$ & $\begin{array}{c}\text { Test-Retest } \\
\text { Reliability (icc) }\end{array}$ & Construct Validity & Convergent Validity & $\begin{array}{c}\text { Divergent } \\
\text { Validity }\end{array}$ & $\begin{array}{c}\text { Discriminant } \\
\text { Validity }\end{array}$ & Content Validity & Face Validity & $\begin{array}{l}\text { Cross-Cultural } \\
\text { Adaptation and/or } \\
\text { Validity }\end{array}$ \\
\hline $\begin{array}{l}\text { Mason et al., } \\
2010 \text { [118] }\end{array}$ & $\begin{array}{l}\text { 23-item } \\
\text { scale }\end{array}$ & $\begin{array}{l}0.87 \text { for the } \\
\text { overall scale }\end{array}$ & NR & NR & NR & NR & NR & $\begin{array}{l}\text { Cognitive } \\
\text { interviews were } \\
\text { used to assess } \\
\text { comprehension } \\
\text { and relevance. } \\
\text { All participants } \\
\text { appeared to } \\
\text { understand the } \\
\text { items as intended. } \\
\text { Items were either } \\
\text { modified or } \\
\text { deleted following } \\
\text { participants' } \\
\text { feedback. }\end{array}$ & NR & $\begin{array}{l}\text { Cognitive } \\
\text { interviews ensured } \\
\text { cultural and } \\
\text { developmental } \\
\text { appropriateness of } \\
\text { the scale. }\end{array}$ \\
\hline $\begin{array}{l}\text { Montano } \\
\text { et al., } 2020 \\
\text { [121] }\end{array}$ & 7-item scale & $\begin{array}{l}0.73 \text { for the } \\
\text { overall scale } \\
0.71 \text { and } 0.74 \text { for } \\
\text { the subscales }\end{array}$ & $\begin{array}{l}0.83 \text { for the } \\
\text { overall scale } \\
0.78 \text { and } 0.79 \text { for } \\
\text { the subscales }\end{array}$ & $\begin{array}{l}\text { Factor analysis yielded } \\
\text { a 2-factor structure } \\
\text { with good model fit: } \\
\text { RMSEA = 0.038; } \\
\text { CFI = } 0.988 \text {, TLI: } 0.981 \\
\text { SRMR }=0.05\end{array}$ & $\begin{array}{l}\text { Positive correlation between the } \\
\text { scale, including subscales, with } \\
\text { depression }(0.26-0.53, p<0.05) \text {. } \\
\text { Negative correlation between the } \\
\text { scale, including subscales, with } \\
\text { adherence }(-0.24--0.31, p<0.05) \\
\text { Negative correlation between } \\
\text { internalized stigma subscale and } \\
\text { CD4 levels }(-0.23, p<0.05) \\
\text { Higher levels of stigma in women } \\
\text { (in all scores), in heterosexual men } \\
\text { (total and enacted), in those not } \\
\text { satisfied with their housing (total } \\
\text { and internalized), in those } \\
\text { previously incarcerated (total and } \\
\text { enacted), not consistently using } \\
\text { condoms (total and enacted), and } \\
\text { detectable viral load (internalized) } \\
\text { All Ps }<0.05\end{array}$ & NR & NR & NR & NR & $\begin{array}{l}\text { Scale translated } \\
\text { to Spanish, } \\
\text { discrepancies in } \\
\text { translation } \\
\text { resolved, } \\
\text { back-translated to } \\
\text { English, and } \\
\text { pilot-tested }\end{array}$ \\
\hline $\begin{array}{l}\text { Rao et al., } \\
2008 \text { [144] }\end{array}$ & $\begin{array}{l}40 \text {-item } \\
\text { scale }\end{array}$ & NR & NR & NR & NR & NR & NR & NR & NR & $\begin{array}{l}11 \text { items showed } \\
\text { differential item } \\
\text { functioning across } \\
\text { ethnic/racial } \\
\text { groups (black vs. } \\
\text { white participants) }\end{array}$ \\
\hline
\end{tabular}


Table 1. Cont.

\begin{tabular}{|c|c|c|c|c|c|c|c|c|c|c|}
\hline \multirow[t]{2}{*}{$\begin{array}{l}\text { First Author } \\
\text { (Year) }\end{array}$} & \multirow[t]{2}{*}{ Scale Used } & \multicolumn{2}{|c|}{ Reliability } & \multicolumn{7}{|c|}{ Validity } \\
\hline & & $\begin{array}{c}\text { Internal } \\
\text { Consistency } \\
\text { (Cronbach's } \\
\text { Alpha unless } \\
\text { Otherwise Stated) }\end{array}$ & $\begin{array}{c}\text { Test-Retest } \\
\text { Reliability (icc) }\end{array}$ & Construct Validity & Convergent Validity & $\begin{array}{c}\text { Divergent } \\
\text { Validity }\end{array}$ & $\begin{array}{l}\text { Discriminant } \\
\text { Validity }\end{array}$ & Content Validity & Face Validity & $\begin{array}{l}\text { Cross-Cultural } \\
\text { Adaptation and/or } \\
\text { Validity }\end{array}$ \\
\hline $\begin{array}{l}\text { Reinius et al., } \\
2017 \text { [147] }\end{array}$ & $\begin{array}{l}\text { 12-item } \\
\text { scale }\end{array}$ & $\begin{array}{l}0.80-0.88 \text { for } \\
\text { the subscales }\end{array}$ & NR & $\begin{array}{l}\text { EFA replicated the } \\
4 \text {-factor structure of the } \\
\text { original scale with } \\
\text { acceptable model fit } \\
\left(\chi^{2}=154.2, \mathrm{df}=48, p<\right. \\
0.001 ; \text { CFI }=0.963 ; \text { TLI } \\
=0.93 \text {; RMSEA }=0.071)\end{array}$ & NR & NR & NR & $\begin{array}{l}\text { Experts judged } \\
\text { that the included } \\
\text { items best } \\
\text { represented the } \\
\text { different aspects } \\
\text { of HIV stigma }\end{array}$ & NR & $\begin{array}{l}\text { This study used a } \\
\text { scale that had } \\
\text { previously been } \\
\text { adapted for use in } \\
\text { this setting }\end{array}$ \\
\hline $\begin{array}{l}\text { Renius et al., } \\
2018 \text { [146] }\end{array}$ & $\begin{array}{l}\text { 32-item } \\
\text { scale }\end{array}$ & NR & NR & NR & NR & NR & NR & NR & NR & $\begin{array}{l}\text { Scales adapted to } \\
\text { local contexts in } \\
\text { the primary } \\
\text { Indian and } \\
\text { Swedish studies } \\
-9 \text { items showed } \\
\text { DIF between } \\
\text { cultures (Sweden, } \\
\text { US and India), and } \\
1 \text { item showed DIF } \\
\text { between males } \\
\text { and females }\end{array}$ \\
\hline $\begin{array}{l}\text { Rongkavilit } \\
\text { et al., } 2010 \\
\text { [22] }\end{array}$ & $\begin{array}{l}40 \text { and } \\
12 \text {-item } \\
\text { scales }\end{array}$ & $\begin{array}{l}0.89 \text { and } 0.75 \text { for } \\
\text { the overall } 40 \text { and } \\
12 \text {-item scales, } \\
\text { respectively. } \\
0.77-0.93 \text { for the } \\
\text { subscales in the } \\
12 \text {-item scale. }\end{array}$ & NR & $\begin{array}{l}\text { EFA of the } 40 \text {-item } \\
\text { scale suggested a } \\
5 \text {-factor structure, with } \\
\text { four consistent with } \\
\text { the original scale. } \\
\text { CFA confirmed that the } \\
\text { 12-item scale retained } \\
\text { the } 4 \text {-factor structure of } \\
\text { the original scale with } \\
\text { satisfactory model fit } \\
\left(\chi^{2} \text { test } p>0.5 ;\right. \\
\text { GFI }=0.90 ; \text { RMSEA } \\
\left.0.02 ; \chi^{2} / \mathrm{df}=1.07\right)\end{array}$ & NR & NR & NR & NR & NR & $\begin{array}{l}\text { Scale was forward } \\
\text { translated to Thai } \\
\text { then back- } \\
\text { translated to } \\
\text { English by } \\
\text { independent } \\
\text { translators }\end{array}$ \\
\hline $\begin{array}{l}\text { Valle et al., } \\
2015 \text { [171] }\end{array}$ & $\begin{array}{l}\text { 21-item } \\
\text { scale }\end{array}$ & $\begin{array}{l}0.88 \text { for the } \\
\text { overall scale. } \\
0.76-0.83 \text { for the } \\
\text { subscales. }\end{array}$ & NR & $\begin{array}{l}\text { EFA extracted a } \\
\text { 4-factor structure with } \\
\text { adequate model fit }\left(\mathrm{\chi}^{2}\right. \\
(210, n=75)=752.413 \\
p<0.001 ; \\
\mathrm{KMO}=0.777)\end{array}$ & $\begin{array}{l}\text { Expected correlation }(\mathrm{r}) \text { between } \\
\text { the overall scale, including } \\
\text { subscales, and measures of } \\
\text { depression }(0.25-0.34, p<0.01) \text { and } \\
\text { self-esteem (significant negative } \\
\text { correlation) }\end{array}$ & NR & $\begin{array}{l}\text { Significant } \\
\text { differences } \\
\text { between the } \\
\text { high score and } \\
\text { low score } \\
\text { groups }(p<0.01 \\
\text { for all subscales) }\end{array}$ & NR & NR & NR \\
\hline
\end{tabular}


Table 1. Cont.

\begin{tabular}{|c|c|c|c|c|c|c|c|c|c|c|}
\hline \multirow[t]{2}{*}{$\begin{array}{l}\text { First Author } \\
\text { (Year) }\end{array}$} & \multirow[t]{2}{*}{ Scale Used } & \multicolumn{2}{|c|}{ Reliability } & \multicolumn{7}{|c|}{ Validity } \\
\hline & & $\begin{array}{c}\text { Internal } \\
\text { Consistency } \\
\text { (Cronbach's } \\
\text { Alpha unless } \\
\text { Otherwise Stated) }\end{array}$ & $\begin{array}{c}\text { Test-Retest } \\
\text { Reliability (icc) }\end{array}$ & Construct Validity & Convergent Validity & $\begin{array}{c}\text { Divergent } \\
\text { Validity }\end{array}$ & $\begin{array}{l}\text { Discriminant } \\
\text { Validity }\end{array}$ & Content Validity & Face Validity & $\begin{array}{c}\text { Cross-Cultural } \\
\text { Adaptation and/or } \\
\text { Validity }\end{array}$ \\
\hline $\begin{array}{l}\text { Wiklander } \\
\text { et al., } 2013 \\
\text { [23] }\end{array}$ & 8-item scale & $\begin{array}{l}0.81 \text { for the } \\
\text { overall scale. } \\
0.55-0.80 \text { for the } \\
\text { subscales }\end{array}$ & NR & $\begin{array}{l}\text { PCA yielded a 3-factor } \\
\text { structure with all items } \\
\text { loading on the same } \\
\text { factors similar to the } \\
\text { original scale } \\
\text { Moderate to high } \\
\text { correlations between } \\
\text { the scale and its } \\
\text { subscales. } \\
\text { Low correlation } \\
\text { between the subscales }\end{array}$ & $\begin{array}{l}\text { Expected correlation }(\mathrm{r}) \text { between } \\
\text { the overall scale, including } \\
\text { subscales, and quality of life } \\
(-0.26--0.49) \\
p<0.05,<0.01 \text {, or }<0.001 \text { for all } \\
\text { correlations except for negative } \\
\text { self-image subscale with social } \\
\text { inclusion subscale }\end{array}$ & NR & NR & NR & NR & $\begin{array}{l}\text { A previously } \\
\text { adapted Swedish } \\
\text { version of the } \\
\text { scale was adapted } \\
\text { to children by } \\
\text { paediatric experts. }\end{array}$ \\
\hline $\begin{array}{l}\text { Wright et al., } \\
2007 \text { [178] }\end{array}$ & $\begin{array}{l}\text { 10-item } \\
\text { scale }\end{array}$ & $\begin{array}{l}0.72-0.84 \text { for } \\
\text { the subscales. }\end{array}$ & NR & $\begin{array}{l}\text { 4-factor structure with } \\
\text { high correlations to the } \\
\text { original scale }\end{array}$ & $\begin{array}{l}\text { Expected correlation (r) between } \\
\text { the overall scale, including } \\
\text { subscales, and depression } \\
(0.35-0.41) \text {, anxiety }(0.24-0.32, \\
\text { social support }(-0.20--0.35) \text {, and } \\
\text { alcohol use }(0.24-0.35) \\
p<0.05 \text { or }<0.01 \text { for all correlations } \\
\text { except for total stigma with anxiety } \\
\text { and negative self-image with social } \\
\text { support and alcohol use }\end{array}$ & NR & NR & NR & NR & NR \\
\hline
\end{tabular}


Table 1. Cont.

\begin{tabular}{|c|c|c|c|c|c|c|c|c|c|c|}
\hline \multirow[t]{2}{*}{$\begin{array}{l}\text { First Author } \\
\text { (Year) }\end{array}$} & \multirow[t]{2}{*}{ Scale Used } & \multicolumn{2}{|c|}{ Reliability } & \multicolumn{7}{|c|}{ Validity } \\
\hline & & $\begin{array}{c}\text { Internal } \\
\text { Consistency } \\
\text { (Cronbach's } \\
\text { Alpha unless } \\
\text { Otherwise Stated) }\end{array}$ & $\begin{array}{c}\text { Test-Retest } \\
\text { Reliability (icc) }\end{array}$ & Construct Validity & Convergent Validity & $\begin{array}{c}\text { Divergent } \\
\text { Validity }\end{array}$ & $\begin{array}{l}\text { Discriminant } \\
\text { Validity }\end{array}$ & Content Validity & Face Validity & $\begin{array}{l}\text { Cross-Cultural } \\
\text { Adaptation and/or } \\
\text { Validity }\end{array}$ \\
\hline $\begin{array}{l}\text { Yu et al., } 2019 \\
\text { [184] }\end{array}$ & $\begin{array}{l}\text { 18-item } \\
\text { scale }\end{array}$ & $\begin{array}{l}0.92 \text { for the } \\
\text { overall scale. } \\
0.73-0.91 \text { for } \\
\text { the subscales. }\end{array}$ & NR & $\begin{array}{l}\text { CFA confirmed a } \\
\text { 4-factor structure } \\
\text { similar to the original } \\
\text { scale with a good model } \\
\text { fit }\left(\chi^{2}=11399.49\right. \\
p<0.01 ; \text { GFI }=0.94 ; \\
\text { AGFI }=0.91 ; \\
\text { RMSEA }=0.55 ; \\
\text { AIC }=420.34)\end{array}$ & $\begin{array}{l}\text { Expected correlation }(\mathrm{r}) \text { between } \\
\text { the overall scale, including } \\
\text { subscales, and depression } \\
(0.25-0.46, p=0.01)\end{array}$ & NR & NR & $\begin{array}{l}\text { Five experts } \\
\text { judged the items } \\
\text { and the scale to } \\
\text { have adequate } \\
\text { content validity in } \\
\text { terms of relevance, } \\
\text { cultural } \\
\text { equivalence, and } \\
\text { clarity (both item } \\
\text { and scales content } \\
\text { validity index score } \\
\text { of 1) }\end{array}$ & NR & $\begin{array}{l}\text { Scale was } \\
\text { translated to } \\
\text { Chinese then } \\
\text { back-translated to } \\
\text { English by three } \\
\text { independent } \\
\text { experts. } \\
\text { Items then } \\
\text { adapted to this } \\
\text { population } \\
\text { following group } \\
\text { discussions } \\
\text { involving experts. } \\
\text { Further } \\
\text { modifications } \\
\text { were made } \\
\text { following a pilot } \\
\text { test and a review } \\
\text { of the tool by } \\
\text { some participants. }\end{array}$ \\
\hline
\end{tabular}

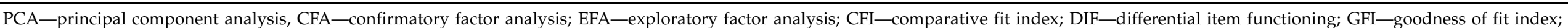

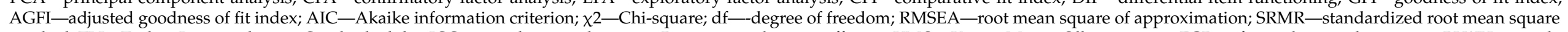

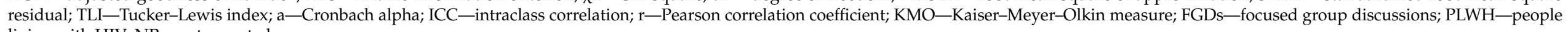
living with HIV; NR-not reported. 


\subsubsection{Content and Face Validity}

Fourteen studies $[20,35,40,63,70,91,97,104,107,111,118,137,147,184]$ evaluated the content validity of the HSS. Of these, three studies $[35,70,91]$ also evaluated the scale's face validity. In three of these studies $[35,104,184]$, content validity was assessed using content validity index, with reported content validity index of 1.00 [184], 0.82 [35], and 0.87 [104]. For the rest of the studies, the items in the scales used were judged to be relevant, comprehensive, clear, or comprehensible by the participants $[40,63,70,91,107,118]$, experts $[20,147]$, and participants with experts [97,111]. In one study [137], the items were selected from a previously published and validated scale to ensure content validity. To assess face validity, item relevance was judged by the participants or the experts in two studies [70,91]. One study [35] assessed face validity using the face validity index and reported a face validity index of 0.56 .

\subsubsection{Construct Validity}

In total, 27 studies assessed the factor structure of the HSS [20,22,23,40,45,60,69-71,91$93,95,97,107,111,121,143,147,156,171,176,178,180,184,190]$. During the development of the initial scale, Berger et al. [20] derived a four-factor solution from the exploratory factor analysis (EFA) that accounted for $46 \%$ of the variance. The four-factor structure was replicated in 14 of these studies [45,60,69-71,91,92,107,111,147,156,171,178,184], often with acceptable-to-good model fit statistics (see Table 1 and Supplementary Table S2). In two studies that assessed construct validity in two versions of the HSS [22,97], the 12- and 10-item versions of the scale in these studies also replicated the four-factor structure of the original scale. However, EFA suggested a five-factor solution in the 40-item version of the scale in a study by Rongkavilit et al. [22] and a three-factor solution in the 13-item version of the scale in a study by Kamitani et al. [97]. Factor analysis for the remaining studies suggested a three-factor solution in two studies [23,176], a two-factor solution in six studies $[40,93,95,121,177,180]$, and a one-factor solution in two studies $[143,190]$.

\subsubsection{Convergent and Divergent Validity}

Twenty studies [20,23,39,40,45,60,63,69,70,91-93,95,97,107,121,133,171,178,184] assessed the convergent validity of the HSS. Of these, one study [97] additionally evaluated the divergent validity of the scale. To assess convergent validity, these studies explored the associations of the HSS with related measures of depression $[20,39,40,60,63,69,91-$ $93,95,121,133,171,178,184]$, anxiety $[40,178]$, self-esteem $[20,39,45,95,133,171]$, social support [20,60,70,178], social integration [20], social conflict [20], bullying victimization [40], peer problems [40], stigmatization [45,92], discrimination [45], fear of discovery [45], quality of life [23,69], physical, psychological, and emotional wellbeing [70,107], life satisfaction [70], self-efficacy [70], disclosure of HIV status [70], sexual abuse [92], overall health status [97], acculturation [97], alcohol use [178], sexuality problems [60], perceived side effects [60], adherence [121], viral load [121], CD4 count levels [93,121], HIV symptoms [93], spirituality/religiousness [93], and sociodemographic indicators (previous incarceration, gender, sexual orientation, consistency of condom use, and satisfaction with housing) [121].

The observed associations between the HSS and these measures in these studies were as hypothesised (see Table 1 and Supplementary Table S2 for correlation coefficients). Overall, there were low to high positive correlations between the scale and measures of depression, anxiety, social conflict, peer problems, bullying victimisation, stigmatisation, discrimination, fear of discovery, sexual abuse, sexuality problems, perceived side effects, HIV symptoms, detectable viral load, previous incarceration, female gender, heterosexual orientation, inconsistent condom use, and alcohol use.

Similarly, but in the inverse direction, there were low to high negative correlations between the scale and measures of self-esteem, social support, social integration, quality of life, life satisfaction, physical, psychological, and emotional well-being, self-efficacy, adherence, CD4 count level, disclosure of HIV status, spirituality / religiousness, overall health status, and acculturation. To assess divergent validity, Kamitani et al. [97] explored 
the associations of the 10- and 13-item versions of the HSS with education level in a sample of Asians living with HIV in the US and found no association $(\mathrm{B}=-0.28, p=0.93)$.

\subsubsection{Discriminant Validity}

Only four studies $[40,70,111,171]$ assessed the discriminant validity of the HSS. First, Boyes et al. [40] evaluated the discriminant validity of a 10-item scale adapted for measuring stigma-by-association among South African youth affected by HIV by comparing its performance among HIV-affected and unaffected youth. As expected, stigma scores were significantly higher among HIV-affected youth $(p<0.001)$.

Second, in a Spanish sample of PLWH, Fuster-RuizdeApodaca et al. [70] evaluated the discriminant validity of a 30-item scale by comparing its performance among participants with and without a history of AIDS-related opportunistic infection. As expected, stigma scores were significantly higher among participants with a history of AIDS-related opportunistic infection $(p=0.003)$.

Third, using a 21-item Spanish version of the scale in Mexico, Valle et al. [171] demonstrated discriminant validity of the scale by finding significant differences between participants with lower and higher stigma scores on the scale $(p<0.01)$. Finally, Luz et al. [111] determined the discriminant validity of a 12-item scale in a Brazilian sample of PLWH by comparing stigma scores based on antiretroviral treatment and adherence status. As expected, in specific samples or across the entire sample, participants who were not on treatment or those with poor adherence showed statistically significant higher subscale scores.

\subsubsection{Cross-Cultural Adaptation and/or Validity}

Three studies $[111,144,146]$ assessed the cross-cultural validity of the HSS by assessing the differential item functioning (DIF) of its items across cultural and ethnic groups. In a 40-item version of the HSS, Rao et al. [144] found 11 items that functioned differently across a sample of black and white American participants. Reinius et al. [146] assessed the DIF of a 32-item version of the scale across Indian, Swedish, and US cohorts of PLWH. This study found nine items that functioned differently between cultures and one item that functioned differently across gender. Luz et al. [111] assessed the DIF of a 12-item version of the scale in a diverse sample of Brazilian participants recruited from different social media platforms (Grindr, Hornet, and WhatsApp/Facebook). They found one item that functioned differently across the three samples.

The cross-cultural adaptation process of the HSS was conducted in 34 studies (Table 1 and Supplementary Table S2). In 23 of these studies [36,39,40,69,70,91,92,94,95,97,107,111, $118,121,125,126,129,132,137,156,159,162,184]$, the scales were adapted to the local contexts following forward and back-translations and review by experts and/or feedback from participant interviews and discussions. Ten of the studies [22,82,98,103-105,118,127,136,164] just translated the scale to the target native languages, while one study [122] adapted a scale that had already been translated in the study setting. Nine studies $[23,35,61,88,116,147,160,170,175]$ did not adapt the scale but used previously adapted versions.

\subsection{Quality of the Included Studies}

Supplementary Table S3 presents the quality ratings of the included development and/or validation studies per the reported psychometric measures using the COSMIN checklist. Three studies $[92,144,146]$ were rated to be of very good quality, eight studies $[22,45,69,93,95,121,178,184]$ to be of adequate quality, nine studies $[20,40,70$, $91,97,111,118,147,171]$ to be of doubtful quality, and four studies $[23,39,63,107]$ to be of inadequate quality.

\section{Discussion}

This review aimed to systematically summarise the available evidence on the psychometric properties of the Berger Stigma Scale. One hundred and sixty-six studies met our inclusion criteria and were reviewed. Most of the included studies (46.4\%) were conducted 
in North America, particularly in the United States. This is not surprising, considering that the scale was first developed and validated for use in this setting. Therefore, a reliable and valid tool for use in this setting was available to researchers. The lack of adequately validated tools for use in a given setting can contribute to the under investigation or underreporting of patient-reported health outcomes. For instance, the paucity of validated screening tools for anxiety disorders has previously been cited as a reason for the lower screening of anxiety disorders among young people living with HIV from sub-Saharan Africa [192].

Most of the included studies (91.6\%) were published from 2010 onwards. This highlights an encouraging increase in the scientific knowledge of HIV-related stigma over the past decade. It is also encouraging to note that the included studies recruited diverse samples of PLWH, including key populations such as MSM, female sex workers, and adolescent girls and young women. This exemplifies the efforts that have been put in place to end HIV / AIDS, including efforts towards understanding HIV-related stigma in such key populations that have been known to be significant contributors to the pandemic $[193,194]$.

\subsection{Psychometric Properties of the HSS}

The internal consistency of the HSS ranged from acceptable to excellent (Cronbach's alpha $\geq 0.70$ [191]) in $93.2 \%$ of the included studies. This suggests that the scale is largely reliable for use across contexts and the diverse population of HIV-positive and negative but affected individuals. Moreover, for the few studies $(n=8)[20,39,52,88,91,92,121,166]$ that reported the test-retest reliability of the scale, the reported intraclass correlation coefficients were above acceptable $(\geq 0.40$ [191]) in seven of these studies. This suggests that the HSS is also stable over time and provides further evidence of the scale's reliability. However, since this was only assessed in a few studies, future studies also need to incorporate this aspect of reliability to confidently ascertain the temporal stability of this scale.

It appears that the four-factor structure of the HSS is stable across contexts and the diverse population of PLWH. Of the 26 studies that assessed the factor structure of the HSS besides the original study, 16 studies (61.5\%) replicated the four-factor structure of the original scale. Although different factor-solutions were suggested in some studies, the suggested solutions were consistent with the number of subscales used $[143,177,180]$. Where different factor solutions were suggested for the full or abbreviated versions, some factors in the suggested solutions were consistent with factors on the original scale. While this suggests that the experiences of HIV-related stigma might be similar across contexts, the differences in factor solutions might be due to cultural, linguistic, and sociodemographic differences $[23,176]$ and differences in the number of items used [121].

Across studies reporting the convergent validity of the HSS, the correlations between the scale and the theoretically related measures were all in the expected direction, providing evidence of convergent validity. Of note, the correlations between the HSS and these measures were not only in the expected direction but also significant in most of the included studies. The observed associations are consistent with findings from a systematic review that assessed the association between HIV-related stigma and various health outcomes [195].

The discriminant validity of the HSS was established in four studies $[40,70,111,171]$. Although limited to only a few studies, the HSS appears to have the ability to distinguish between people with a higher and lower risk of HIV-related stigma. This suggests that the scale is sensitive to HIV-related stigma and provides strong evidence of validity [196]. However, four studies indicate a very thin evidence base, thus the need for more research focusing on correlating the HSS with biomarkers of HIV, e.g., medical adherence, viral load, and CD4 count. Additionally, the HSS could be used in longitudinal studies to try and see to what extent it is sensitive to change since this is what will make it useful for interventions.

Although the HSS has been translated and/or adapted to target settings, evidence of cross-cultural validity remains limited. Only three of the included studies $[111,144,146]$ 
assessed and established the cross-cultural validity of the HSS through DIF. More crosscultural validation work of the HSS is needed to determine its performance across different cultures and contexts. Despite this, the scale appears to have content and face validity across contexts, although this is limited as it was only assessed in 14 of the included studies. Overall, the evidence of reliability and validity (although limited) from this review suggests that the HSS is psychometrically sound to assess HIV-related stigma across contexts and the diverse population of HIV-positive and negative but affected people.

\subsection{Limitations of the Review}

This review was not without limitations. First, we restricted our search to studies that were only published in the English language. Consequently, we may have left out relevant studies published in different languages. Second, we could not rate the quality of the included observational or experimental studies because of the nature of our chosen rating tool. Because of this, it is difficult to ascertain the strength of evidence of the results from these studies. Finally, we could not conduct a meta-analysis because of the heterogeneity in the versions of the HSS used as well as the sub-populations involved. Because we could not conduct a meta-analysis, we could not also assess and report on publication bias.

\subsection{Implications of the Findings to Practice and Future Research}

There is a need for more validation work to ascertain the validity of the HSS across contexts. Only $21.7 \%(n=36)$ of the included studies reported an aspect of the validity of the HSS, while the remaining studies only reported reliability. This validation work is needed even more in African, Asian, Oceania, and South American settings, where there is minimal information on the validity of the HSS. Of the 36 studies reporting on an aspect of validity, more than half of these studies $(58.3 \%, n=21)$ came from North America and Europe. The rest were distributed across Africa [40,133,137], Asia [22,35,39,91,95,104,143,180,184], and South America $[69,111,121]$. No study was from Oceania. The distribution of the validation studies reflects a bias towards the global North. This may be because most of the funding for research is in the global North [197] although the highest disease burden is in lowand middle-income countries [1]. This highlights a need for more research investments in low- and middle-income countries. That said, where reported, the HSS appears to have good psychometric properties across contexts and across the diverse population HIVpositive and negative but affected people, particularly reliability. Therefore, researchers and related practitioners may use this measure in their contexts following some validation work as needed.

\section{Conclusions}

The measurement of HIV-related stigma has the potential to help identify individuals at risk of poor psychological outcomes and inform the development and evaluation of HIVstigma reduction interventions. However, this requires the availability of psychometrically sound measures for use among the target populations. The HSS is an example of such measures and is one of the most widely used measures of HIV-related stigma. According to this review, the HSS appears to be a reliable and valid measure of HIV-related stigma across contexts. However, evidence of validity is limited, particularly for African, Asian, Oceanian, and South American settings. This calls for more context-specific validation work of the HSS. The HSS may be used to assess HIV-related stigma following context-specific work as needed.

Supplementary Materials: The following are available online at https:/ / www.mdpi.com/article/10 .3390/ijerph182413074/s1, Supplementary File S1: Search string used in PubMed, Table S1: Characteristics of included studies, Table S2: Psychometric properties of the HSS as reported by the observational or experimental studies, Table S3: Quality ratings of the included development and/or validation studies. 
Author Contributions: Conceptualisation, A.A., S.L. and S.W.W.; Methodology, A.A., S.L., E.K.T. and S.W.W.; Software, Endnote X9 and EPPI Reviewer; Quality assessment, S.W.W. and E.K.T.; Applied synthesis method, S.W.W. and E.K.T.; Writing—original draft preparation, S.W.W.; Writing-review and editing, S.W.W., E.K.T., S.L. and A.A.; Supervision, S.L. and A.A.; Funding acquisition, A.A. All authors read, provided feedback and approved the published version of the manuscript. All authors have read and agreed to the published version of the manuscript.

Funding: This research was supported by the Medical Research Council (Grant number MR/M025454/1) to A.A. This award is jointly funded by the UK Medical Research Council (MRC) and the UK Department for International Development (DFID) under MRC/DFID concordant agreement and is also part of the EDCTP2 program supported by the European Union. The funders had no role in the study's design, in the collection, analyses, or interpretation of data, in the writing of the manuscript, or in the decision to publish the results.

Institutional Review Board Statement: Not applicable.

Informed Consent Statement: Not applicable.

Data Availability Statement: The data supporting the conclusions presented in this article are available within this article and the Supplementary Materials.

Acknowledgments: We appreciate Paul Mwangi for helping develop a world map showing the geographic distribution of the included studies.

Conflicts of Interest: The authors declare no conflict of interest.

\section{References}

1. UNAIDS. Global Hiv \& Aids Statistics-Fact Sheet. Available online: https://www.unaids.org/en/resources/fact-sheet (accessed on 28 November 2021).

2. World Health Organization. Global Health Estimates 2020: Deaths by Cause, Age, Sex, by Country and by Region, 2000-2019; WHO: Geneva, Switzerland, 2020.

3. Gamarel, K.E.; Nelson, K.M.; Stephenson, R.; Rivera, O.J.S.; Chiaramonte, D.; Miller, R.L.; The Adolescent Medicine Trials Network for HIV / AIDS Interventions. Anticipated Hiv Stigma and Delays in Regular Hiv Testing Behaviors among SexuallyActive Young Gay, Bisexual, and Other Men Who Have Sex with Men and Transgender Women. AIDS Behav. 2017, 22, 522-530. [CrossRef] [PubMed]

4. Sullivan, M.; Rosen, A.O.; Allen, A.; Benbella, D.; Camacho, G.; Cortopassi, A.C.; Driver, R.; Ssenyonjo, J.; Eaton, L.A.; Kalichman, S.C. Falling Short of the First 90: HIV Stigma and HIV Testing Research in the 90-90-90 Era. AIDS Behav. 2020, $24,357-362$. [CrossRef]

5. Sayles, J.N.; Wong, M.; Kinsler, J.J.; Martins, D.; Cunningham, W.E. The Association of Stigma with Self-Reported Access to Medical Care and Antiretroviral Therapy Adherence in Persons Living with HIV/AIDS. J. Gen. Intern. Med. 2009, 24, 1101-1108. [CrossRef]

6. Helms, C.B.; Turan, J.M.; Atkins, G.; Kempf, M.-C.; Clay, O.J.; Raper, J.L.; Mugavero, M.J.; Turan, B. Interpersonal Mechanisms Contributing to the Association Between HIV-Related Internalized Stigma and Medication Adherence. AIDS Behav. 2017, 21, 238-247. [CrossRef] [PubMed]

7. Layer, E.H.; Kennedy, C.E.; Beckham, S.W.; Mbwambo, J.K.; Likindikoki, S.; Davis, W.W.; Kerrigan, D.L.; Brahmbhatt, H.; the LTC Tanzania Collaborative Study Team. Multi-Level Factors Affecting Entry into and Engagement in the HIV Continuum of Care in Iringa, Tanzania. PLoS ONE 2014, 9, e104961. [CrossRef]

8. Ayieko, J.; Brown, L.; Anthierens, S.; Van Rie, A.; Getahun, M.; Charlebois, E.D.; Petersen, M.L.; Clark, T.D.; Kamya, M.R.; Cohen, C.R.; et al. "Hurdles on the path to 90-90-90 and beyond": Qualitative analysis of barriers to engagement in HIV care among individuals in rural East Africa in the context of test-and-treat. PLoS ONE 2018, 13, e0202990. [CrossRef]

9. Kay, E.S.; Rice, W.; Crockett, K.B.; Atkins, G.C.; Batey, D.S.; Turan, B. Experienced HIV-Related Stigma in Health Care and Community Settings: Mediated Associations with Psychosocial and Health Outcomes. J. Acquir. Immune Defic. Syndr. 2018, 77, 257-263. [CrossRef]

10. Luo, H.; Sun, M.; Du, J. Associated factors for progression to AIDS among HIV-infected people who use drugs: A retrospective cohort study in Dongguan, China. BMJ Open 2019, 9, e023841. [CrossRef] [PubMed]

11. Bilardi, J.E.; Hulme, A.; Chen, M.Y.; Fairley, C.K.; Huffam, S.E.; Tomnay, J.E. The role of stigma in the acceptance and disclosure of HIV among recently diagnosed men who have sex with men in Australia: A qualitative study. PLoS ONE 2019, 14, e0224616. [CrossRef]

12. Visser, M.J.; Kershaw, T.S.; Makin, J.D.; Forsyth, B.W.C. Development of Parallel Scales to Measure HIV-Related Stigma. AIDS Behav. 2008, 12, 759-771. [CrossRef]

13. Kalichman, S.C.; Simbayi, L.C.; Cloete, A.; Mthembu, P.P.; Mkhonta, R.N.; Ginindza, T.G. Measuring AIDS stigmas in people living with HIV/AIDS: The Internalized AIDS-Related Stigma Scale. AIDS Care 2008, 21, 87-93. [CrossRef] 
14. Fife, B.L.; Wright, E.R. The Dimensionality of Stigma: A Comparison of Its Impact on the Self of Persons with HIV/AIDS and Cancer. J. Health Soc. Behav. 2000, 41, 50-67. [CrossRef] [PubMed]

15. Van Rie, A.; Sengupta, S.; Pungrassami, P.; Balthip, Q.; Choonuan, S.; Kasetjaroen, Y.; Strauss, R.P.; Chongsuvivatwong, V. Measuring stigma associated with tuberculosis and HIV/AIDS in southern Thailand: Exploratory and confirmatory factor analyses of two new scales. Trop. Med. Int. Health 2008, 13, 21-30. [CrossRef] [PubMed]

16. Sowell, R.L.; Lowenstein, A.; Moneyham, L.; Demi, A.; Mizuno, Y.; Seals, B.F. Resources, Stigma, and Patterns of Disclosure in Rural Women with HIV Infection. Public Health Nurs. 1997, 14, 302-312. [CrossRef] [PubMed]

17. Holzemer, W.L.; Uys, L.R.; Chirwa, M.L.; Greeff, M.; Makoae, L.N.; Kohi, T.W.; Dlamini, P.S.; Stewart, A.L.; Mullan, J.; Phetlhu, R.D.; et al. Validation of the HIV/AIDS Stigma Instrument-PLWA (HASI-P). AIDS Care 2007, 19, 1002-1012. [CrossRef] [PubMed]

18. Earnshaw, V.A.; Smith, L.R.; Chaudoir, S.R.; Amico, K.R.; Copenhaver, M.M. HIV Stigma Mechanisms and Well-Being Among PLWH: A Test of the HIV Stigma Framework. AIDS Behav. 2013, 17, 1785-1795. [CrossRef]

19. SSayles, J.N.; Hays, R.D.; Sarkisian, C.A.; Mahajan, A.P.; Spritzer, K.L.; Cunningham, W.E. Development and Psychometric Assessment of a Multidimensional Measure of Internalized HIV Stigma in a Sample of HIV-positive Adults. AIDS Behav. 2008, 12, 748-758. [CrossRef] [PubMed]

20. Berger, B.E.; Ferrans, C.E.; Lashley, F.R. Measuring stigma in people with HIV: Psychometric assessment of the HIV stigma scale. Res. Nurs. Health 2001, 24, 518-529. [CrossRef]

21. Souza, A.C.D.; Alexandre, N.M.C.; Guirardello, E.D.B. Psychometric Properties in Instruments Evaluation of Reliability and Validity. Epidemiol. Serv. Saúde 2017, 26, 649-659. [CrossRef] [PubMed]

22. Rongkavilit, C.; Wright, K.; Chen, X.; Naar-King, S.; Chuenyam, T.; Phanuphak, P. HIV stigma, disclosure and psychosocial distress among Thai youth living with HIV. Int. J. STD AIDS 2010, 21, 126-132. [CrossRef] [PubMed]

23. Wiklander, M.; Rydström, L.-L.; Ygge, B.-M.; Navér, L.; Wettergren, L.; Eriksson, L.E. Psychometric properties of a short version of the HIV stigma scale, adapted for children with HIV infection. Health Qual. Life Outcomes 2013, 11, 195. [CrossRef]

24. Dowshen, N.; Binns, H.J.; Garofalo, R. Experiences of HIV-Related Stigma Among Young Men Who Have Sex with Men. AIDS Patient Care STDs 2009, 23, 371-376. [CrossRef] [PubMed]

25. Irmayati, N.; Yona, S.; Waluyo, A. HIV-Related Stigma, Knowledge about HIV, HIV Risk Behavior and HIV Testing Motivation among Women in Lampung, Indonesia. Enferm. Clin. 2019, 29, 546-550. [CrossRef]

26. Moher, D.; Shamseer, L.; Clarke, M.; Ghersi, D.; Liberati, A.; Petticrew, M.; Shekelle, P.; Stewart, L.A. Preferred reporting items for systematic review and meta-analysis protocols (PRISMA-P) 2015 statement. Syst. Rev. 2015, 4, 1. [CrossRef]

27. Mokkink, L.B. Cosmin Risk of Bias Checklist; Amsterdam Public Health Research Institute: Amsterdam, The Netherlands, 2018.

28. Mokkink, L.B.; Terwee, C.B.; Patrick, D.L.; Alonso, J.; Stratford, P.; Knol, D.L.; Bouter, L.M.; De Vet, H.C.W. The Cosmin Checklist for Assessing the Methodological Quality of Studies on Measurement Properties of Health Status Measurement Instruments: An International Delphi Study. Qual. Life Res. 2010, 19, 539-549. [CrossRef] [PubMed]

29. Mokkink, L.B.; De Vet, H.C.W.; Prinsen, C.A.C.; Patrick, D.L.; Alonso, J.; Bouter, L.; Terwee, C.B. COSMIN Risk of Bias checklist for systematic reviews of Patient-Reported Outcome Measures. Qual. Life Res. 2017, 27, 1171-1179. [CrossRef]

30. Terwee, C.B.; Mokkink, L.B.; Knol, D.L.; Ostelo, R.; Bouter, L.; De Vet, H.C.W. Rating the methodological quality in systematic reviews of studies on measurement properties: A scoring system for the COSMIN checklist. Qual. Life Res. 2011, 21, 651-657. [CrossRef] [PubMed]

31. Abbamonte, J.M.; Parrish, M.S.; Lee, T.K.; Ramlagan, S.; Sifunda, S.; Peltzer, K.; Weiss, S.M.; Jones, D.L. Influence of Male Partners on HIV Disclosure Among South African Women in a Cluster Randomized PMTCT Intervention. AIDS Behav. 2021, 25, 604-614. [CrossRef] [PubMed]

32. Anakwa, N.O.; Teye-Kwadjo, E.; Kretchy, I.A. Effect of HIV-Related Stigma and HIV-Related Stress on HIV Disclosure Concerns: A Study of HIV-Positive Persons on Antiretroviral Therapy at Two Urban Hospitals in Ghana. Appl. Res. Qual. Life 2021, 16, 1249-1264. [CrossRef]

33. Andrinopoulos, K.; Clum, G.; Murphy, D.A.; Harper, G.; Perez, L.; Xu, J.; Cunningham, S.; Ellen, J.M.; the Adolescent Medicine Trials Network for HIV / AIDS Interventions. Health Related Quality of Life and Psychosocial Correlates among HIV-Infected Adolescent and Young Adult Women in the US. AIDS Educ. Prev. 2011, 23, 367-381. [CrossRef]

34. Aristegui, I.; Radusky, P.D.; Zalazar, V.; Cardozo, N.; Fabian, S.; Duarte, M.; Frola, C.; Cahn, P.; Sued, O. Correlates of depressive symptoms in transgender women initiating HIV treatment in Argentina. J. Gay Lesbian Ment. Health 2021, 25, 208-225. [CrossRef]

35. Arshi, M.; Yavari, M.; Azad, H.F.; Safi, M.H.; Moghanibashi-Mansourieh, A.; Moshayyedi, M. Investigation of Relationship between Family Social Support and the Level of Stigma Perceived by PLWHA in Iran. Soc. Work. Public Health 2020, 35, 90-99. [CrossRef] [PubMed]

36. Ataro, Z.; Mengesha, M.M.; Abrham, A.; Digaffe, T. Gender Differences in Perceived Stigma and Coping Strategies Among People Living with HIV / AIDS at Jugal Hospital, Harar, Ethiopia. Psychol. Res. Behav. Manag. 2020, 13, 1191-1200. [CrossRef] [PubMed]

37. Baik, D.; Liu, J.; Cho, H.; Schnall, R. Factors Related to Biological Sex Differences in Engagement with Healthcare Providers in Persons Living with HIV. AIDS Behav. 2020, 24, 2656-2665. [CrossRef]

38. Bennett, D.S.; Hersh, J.; Herres, J.; Foster, J. HIV-Related Stigma, Shame, and Avoidant Coping: Risk Factors for Internalizing Symptoms Among Youth Living with HIV? Child Psychiatry Hum. Dev. 2016, 47, 657-664. [CrossRef] [PubMed] 
39. Saif, S.B.-E.; Shahzad, S. Urdu translation and adaptation of the HIV stigma scale in Pakistan injectable drug users with HIV. J. Pak. Med. Assoc. 2020, 70, 505-510. [CrossRef] [PubMed]

40. Boyes, M.E.; Mason, S.J.; Cluver, L.D. Validation of a brief stigma-by-association scale for use with HIV/AIDS-affected youth in South Africa. AIDS Care 2012, 25, 215-222. [CrossRef] [PubMed]

41. Brener, L.; Callander, D.; Slavin, S.; De Wit, J. Experiences of HIV stigma: The role of visible symptoms, HIV centrality and community attachment for people living with HIV. AIDS Care 2013, 25, 1166-1173. [CrossRef] [PubMed]

42. Brown, M.J.; Serovich, J.M.; Kimberly, J.A.; Hu, J. Psychological reactance and HIV-related stigma among women living with HIV. AIDS Care 2016, 28, 745-749. [CrossRef]

43. Brown, M.J.; Serovich, J.M.; Laschober, T.C.; Kimberly, J.A.; Lescano, C.M. Ways of coping and perceived HIV-related stigma among people living with HIV: Moderation by sex and sexual orientation. Psychol. Health Med. 2020, 25, 867-878. [CrossRef]

44. Brown, M.J.; Trask, J.S.; Zhang, J.; Haider, M.R.; Li, X. Sociodemographic and psychosocial correlates of resilience among older adults living with HIV in the Deep South. J. Health Psychol. 2020, 26, 2010-2019. [CrossRef] [PubMed]

45. Bunn, J.Y.; Solomon, S.E.; Miller, C.; Forehand, R. Measurement of Stigma in People with HIV: A Reexamination of the HIV Stigma Scale. AIDS Educ. Prev. 2007, 19, 198-208. [CrossRef] [PubMed]

46. Buseh, A.G.; Kelber, S.T.; Stevens, P.E.; Park, C.G. Relationship of Symptoms, Perceived Health, and Stigma with Quality of Life Among Urban HIV-Infected African American Men: Populations at Risk across the Lifespan: Empirical Studies. Public Health Nurs. 2008, 25, 409-419. [CrossRef]

47. Caliari, J.D.S.; Teles, S.A.; Reis, R.K.; Gir, E. Factors related to the perceived stigmatization of people living with HIV. Rev. Esc. Enferm. USP 2017, 51, e03248. [CrossRef]

48. Cama, E.; Brener, L.; Slavin, S.; De Wit, J. The impact of HIV treatment-related stigma on uptake of antiretroviral therapy. AIDS Care 2015, 27, 739-742. [CrossRef] [PubMed]

49. Carrizosa, C.M.; Blumberg, E.J.; Hovell, M.F.; Martinez-Donate, A.P.; Garcia-Gonzalez, G.; Lozada, R.; Kelley, N.J.; Hofstetter, C.R.; Sipan, C.L. Determinants and Prevalence of Late HIV Testing in Tijuana, Mexico. AIDS Patient Care STDs 2010, 24, 333-340. [CrossRef] [PubMed]

50. Cederbaum, J.A.; Rice, E.; Craddock, J.; Pimentel, V.; Beaver, P. Social networks of HIV-positive women and their association with social support and depression symptoms. Women Health 2017, 57, 268-282. [CrossRef]

51. Cernigliaro, D.; Barrington, C.; Perez, M.; Donastorg, Y.; Kerrigan, D. Factors Related to Pregnancy Among Female Sex Workers Living with HIV in the Dominican Republic. AIDS Behav. 2016, 20, 2346-2356. [CrossRef]

52. Charles, B.; Jeyaseelan, L.; Pandian, A.K.; Sam, A.E.; Thenmozhi, M.; Jayaseelan, V. Association between stigma, depression and quality of life of people living with HIV/AIDS (PLHA) in South India-A community based cross sectional study. BMC Public Health 2012, 12, 463. [CrossRef] [PubMed]

53. Chen, C.; Huang, J.; Zhao, J.; Zhang, Y.; Yu, N.X. Resilience Moderated the Predictive Effect of Dual Stigma on Distress Among Chinese Newly Diagnosed HIV-Positive Men Who Have Sex with Men. AIDS Educ. Prev. 2020, 32, 403-415. [CrossRef] [PubMed]

54. Clum, G.; Chung, S.-E.; Ellen, J.M.; The Adolescent Medicine Trials Network for HIV/AIDS Interventions. Mediators of HIV-related stigma and risk behavior in HIV infected young women. AIDS Care 2009, 21, 1455-1462. [CrossRef]

55. Cluver, L.D.; Gardner, F.; Operario, D. Effects of Stigma on the Mental Health of Adolescents Orphaned by AIDS. J. Adolesc. Health 2008, 42, 410-417. [CrossRef] [PubMed]

56. Colbert, A.M.; Kim, K.H.; Sereika, S.M.; Erlen, J.A. An Examination of the Relationships Among Gender, Health Status, Social Support, and HIV-Related Stigma. J. Assoc. Nurses AIDS Care 2010, 21, 302-313. [CrossRef] [PubMed]

57. Crockett, K.B.; Esensoy, T.A.; Johnson, M.O.; Neilands, T.B.; Kempf, M.-C.; Konkle-Parker, D.; Wingood, G.; Tien, P.C.; Cohen, M.; Wilson, T.E.; et al. Internalized HIV Stigma and Pain among Women with HIV in the United States: The Mediating Role of Depressive Symptoms. AIDS Behav. 2020, 24, 3482-3490. [CrossRef] [PubMed]

58. Cuca, Y.P.; Asher, A.; Okonsky, J.; Kaihura, A.; Dawson-Rose, C.; Webel, A. HIV Stigma and Social Capital in Women Living with HIV. J. Assoc. Nurses AIDS Care 2017, 28, 45-54. [CrossRef] [PubMed]

59. Deering, K.N.; Logie, C.; Krüsi, A.; Ranville, F.; Braschel, M.; Duff, P.; Shannon, K. Prevalence and Correlates of HIV Stigma Among Women Living with HIV in Metro Vancouver, Canada. AIDS Behav. 2021, 25, 1688-1698. [CrossRef]

60. Den Daas, C.; van den Berk, G.E.L.; Kleene, M.-J.T.; de Munnik, E.S.; Lijmer, J.G.; Brinkman, K. Health-related quality of life among adult HIV positive patients: Assessing comprehensive themes and interrelated associations. Qual. Life Res. 2019, 28, 2685-2694. [CrossRef]

61. Drewes, J.; Langer, P.C.; Ebert, J.; Kleiber, D.; Gusy, B. Associations Between Experienced and Internalized HIV Stigma, Adversarial Growth, and Health Outcomes in a Nationwide Sample of People Aging with HIV in Germany. AIDS Behav. 2021, 25, 1037-1046. [CrossRef]

62. Durteste, M.; Kyselyova, G.; Volokha, A.; Judd, A.; Thorne, C.; Cortina-Borja, M.; Malyuta, R.; Martsynovska, V.; Nizova, N.; Bailey, H.; et al. Anxiety symptoms and felt stigma among young people living with perinatally or behaviourally-acquired HIV in Ukraine: A cross-sectional survey. PLoS ONE 2019, 14, e0210412. [CrossRef]

63. Emlet, C.A. Extending the Use of the 40-Item HIV-Stigma Scale to Older Adults: An Examination of Reliability and Validity. J. HIV/AIDS Soc. Serv. 2007, 6, 43-54. [CrossRef]

64. Emlet, C.A.; Brennan, D.J.; Brennenstuhl, S.; Rueda, S.; Hart, T.; Rourke, S.B. The impact of HIV-related stigma on older and younger adults living with HIV disease: Does age matter? AIDS Care 2015, 27, 520-528. [CrossRef] [PubMed] 
65. Fair, C.D.; Ba, B.G. HIV-Related Stigma, Discrimination, and Knowledge of Legal Rights among Infected Adults. J. HIV/AIDS Soc. Serv. 2010, 9, 77-89. [CrossRef]

66. Fekete, E.M.; Williams, S.L.; Skinta, M.D. Internalised HIV-stigma, loneliness, depressive symptoms and sleep quality in people living with HIV. Psychol. Health 2018, 33, 398-415. [CrossRef] [PubMed]

67. Felker-Kantor, E.A.; Wallace, M.E.; Madkour, A.S.; Duncan, D.T.; Andrinopoulos, K.; Theall, K. HIV Stigma, Mental Health, and Alcohol Use Disorders among People Living with HIV/AIDS in New Orleans. J. Urban Health 2019, 96, 878-888. [CrossRef]

68. Filiatreau, L.M.; Wright, M.; Kimaru, L.J.; Gómez-Olivé, F.X.; Selin, A.; Twine, R.; Kahn, K.; Pettifor, A. Correlates of ART Use Among Newly Diagnosed HIV Positive Adolescent Girls and Young Women Enrolled in HPTN 068. AIDS Behav. 2020, 24, 2606-2615. [CrossRef] [PubMed]

69. Franke, M.F.; Muñoz, M.; Finnegan, K.; Zeladita, J.; Sebastian, J.L.; Bayona, J.N.; Shin, S.S. Validation and Abbreviation of an HIV Stigma Scale in an Adult Spanish-Speaking Population in Urban Peru. AIDS Behav. 2010, 14, 189-199. [CrossRef]

70. Fuster-RuizdeApodaca, M.J.; Molero, F.; Holgado, F.P.; Ubillos, S. Adaptation of the HIV Stigma Scale in Spaniards with HIV. Span. J. Psychol. 2015, 18, E66. [CrossRef]

71. Galvan, F.H.; Davis, E.M.; Banks, D.; Bing, E.G. HIV Stigma and Social Support among African Americans. AIDS Patient Care STDs 2008, 22, 423-436. [CrossRef] [PubMed]

72. Gamarel, K.E.; Finer, Z.; Resnicow, K.; Green-Jones, M.; Kelley, E.; Jadwin-Cakmak, L.; Outlaw, A. Associations Between Internalized HIV Stigma and Tobacco Smoking Among Adolescents and Young Adults Living with HIV: The Moderating Role of Future Orientations. AIDS Behav. 2020, 24, 165-172. [CrossRef] [PubMed]

73. Gao, M.; Xiao, C.; Zhang, X.; Li, S.; Yan, H. Social capital and PTSD among PLWHA in China: The mediating role of resilience and internalized stigma. Psychol. Health Med. 2018, 23, 698-706. [CrossRef] [PubMed]

74. Golub, S.A.; Tomassilli, J.C.; Parsons, J.T. Partner Serostatus and Disclosure Stigma: Implications for Physical and Mental Health Outcomes Among HIV-positive Adults. AIDS Behav. 2009, 13, 1233-1240. [CrossRef]

75. Gonzalez, A.; Grover, K.W.; Miller, C.T.; Solomon, S.E. A Preliminary Examination of Sexual Orientation as a Social Vulnerability for Experiencing HIV-/AIDS-Related Stigma. J. Appl. Soc. Psychol. 2011, 41, 1258-1274. [CrossRef] [PubMed]

76. Gonzalez, A.; Miller, C.T.; Solomon, S.E.; Bunn, J.Y.; Cassidy, D.G. Size Matters: Community Size, HIV Stigma, \& Gender Differences. AIDS Behav. 2009, 13, 1205-1212. [CrossRef] [PubMed]

77. Grov, C.; Golub, S.A.; Parsons, J.; Brennan, M.; Karpiak, S.E. Loneliness and HIV-related stigma explain depression among older HIV-positive adults. AIDS Care 2010, 22, 630-639. [CrossRef] [PubMed]

78. Ha, T.; Schensul, S.L.; Irving, M.; Brault, M.; Schensul, J.J.; Prabhughate, P.; Vaz, M. Depression Among Alcohol Consuming, HIV Positive Men on ART Treatment in India. AIDS Behav. 2019, 23, 1623-1633. [CrossRef] [PubMed]

79. Halkitis, P.N.; Perez-Figueroa, R.E.; Carreiro, T.; Kingdon, M.J.; Kupprat, S.A.; Eddy, J. Psychosocial burdens negatively impact HIV antiretroviral adherence in gay, bisexual, and other men who have sex with men aged 50 and older. AIDS Care 2014, 26, 1426-1434. [CrossRef]

80. Harper, G.W.; Lemos, D.; Hosek, S.G. Stigma Reduction in Adolescents and Young Adults Newly Diagnosed with HIV: Findings from the Project ACCEPT Intervention. AIDS Patient Care STDs 2014, 28, 543-554. [CrossRef] [PubMed]

81. Harris, L.M.; Crawford, T.N.; Kerr, J.C.; Thomas, T.A.; Schmidt, V. African American Older Adults Living with HIV: Exploring Stress, Stigma, and Engagement in HIV Care. J. Health Care Poor Underserved 2020, 31, 265-286. [CrossRef]

82. Holzemer, W.L.; Human, S.; Arudo, J.; Rosa, M.E.; Hamilton, M.J.; Corless, I.; Robinson, L.; Nicholas, P.K.; Wantland, D.J.; Moezzi, S.; et al. Exploring HIV Stigma and Quality of Life for Persons Living with HIV Infection. J. Assoc. Nurses AIDS Care 2009, 20, 161-168. [CrossRef] [PubMed]

83. Hosek, S.G.; Harper, G.W.; Lemos, D.; Burke-Miller, J.; Lee, S.; Friedman, L.; Martinez, J. Project ACCEPT: Evaluation of a Group-Based Intervention to Improve Engagement in Care for Youth Newly Diagnosed with HIV. AIDS Behav. 2018, 22, $2650-2661$. [CrossRef]

84. Huang, F.; Chen, W.-T.; Shiu, C.-S.; Sun, W.; Toma, L.; Luu, B.V.; Ah-Yune, J. Acculturation, HIV-Related Stigma, Stress, and Patient-Healthcare Provider Relationships Among HIV-Infected Asian Americans: A Path Analysis. J. Immigr. Minor. Health 2020, 22, 1217-1224. [CrossRef]

85. Hubach, R.D.; Dodge, B.; Li, M.J.; Schick, V.; Herbenick, D.; Ramos, W.D.; Cola, T.; Reece, M. Loneliness, HIV-Related Stigma, and Condom Use Among a Predominantly Rural Sample of HIV-Positive Men Who Have Sex with Men (MSM). AIDS Educ. Prev. 2015, 27, 72-83. [CrossRef] [PubMed]

86. Hussen, S.A.; Harper, G.W.; Bauermeister, J.A.; Hightow-Weidman, L.B. Psychosocial Influences on Engagement in Care Among HIV-Positive Young Black Gay/Bisexual and Other Men Who Have Sex with Men. AIDS Patient Care STDs 2015, $29,77-85$. [CrossRef]

87. Hutson, S.P.; Darlington, C.K.; Hall, J.M.; Heidel, R.E.; Gaskins, S. Stigma and Spiritual Well-being among People Living with HIV / AIDS in Southern Appalachia. Issues Ment. Health Nurs. 2018, 39, 482-489. [CrossRef] [PubMed]

88. Ibrahim, K.; Lindayani, L.; Emaliyawati, E.; Rahayu, U.; Nuraeni, A. Factors Associated with Adherence to Antiretroviral Therapy among People Living with Hiv Infection in West Java Province, Indonesia. Malays. J. Med. Health Sci. 2020, 16, $209-214$.

89. Ivanova, E.L.; Hart, T.A.; Wagner, A.C.; Aljassem, K.; Loutfy, M.R. Correlates of Anxiety in Women Living with HIV of Reproductive Age. AIDS Behav. 2012, 16, 2181-2191. [CrossRef] 
90. Jaworsky, D.; Logie, C.; Wagner, A.; Conway, T.; Kaida, A.; De Pokomandy, A.; Webster, K.; Proulx-Boucher, K.; Sereda, P.; Loutfy, M.; et al. Geographic differences in the experiences of HIV-related stigma for women living with HIV in northern and rural communities of Ontario, Canada. Rural. Remote. Health 2018, 18, 4522. [CrossRef] [PubMed]

91. Jeyaseelan, L.; Kumar, S.; Mohanraj, R.; Rebekah, G.; Rao, D.; Manhart, L.E. Assessing HIV/AIDS Stigma in South India: Validation and Abridgement of the Berger HIV Stigma Scale. AIDS Behav. 2013, 17, 434-443. [CrossRef] [PubMed]

92. Jimenez, J.C.; Puig, M.; Ramos, J.C.; Morales, M.; Asencio, G.; Sala, A.C.; Castro, E.; Santori, C.V.; Santiago, L.; Zorrilla, C. Measuring HIV felt stigma: A culturally adapted scale targeting PLWHA in Puerto Rico. AIDS Care 2010, 22, 1314-1322. [CrossRef] [PubMed]

93. Johnson, E.T.; Yaghmaian, R.A.; Best, A.; Chan, F.; Burrell, R., Jr. Evaluating the Measurement Structure of the Abbreviated HIV Stigma Scale in a Sample of African Americans Living with HIV/AIDS. Rehabil. Res. Policy Educ. 2016, 30, 65-76. [CrossRef]

94. Kaai, S.; Bullock, S.; Sarna, A.; Chersich, M.; Luchters, S.; Geibel, S.; Munyao, P.; Mandaliya, K.; Temmerman, M.; Rutenberg, N. Perceived stigma among patients receiving antiretroviral treatment: A prospective randomised trial comparing an $\mathrm{m}-\mathrm{DOT}$ strategy with standard-of- care in Kenya. SAHARA-J J. Soc. Asp. HIV/AIDS 2010, 7, 62-70. [CrossRef] [PubMed]

95. Kagiura, F.; Fujii, T.; Kihana, N.; Maruyama, E.; Shimoji, Y.; Kakehashi, M. Brief HIV stigma scale for Japanese people living with HIV: Validation and restructuring using questionnaire survey data. AIDS Care 2020, 32, 1-9. [CrossRef] [PubMed]

96. Kamen, C.; Vorasarun, C.; Canning, T.; Kienitz, E.; Weiss, C.; Flores, S.; Etter, D.; Lee, S.; Gore-Felton, C. The Impact of Stigma and Social Support on Development of Post-traumatic Growth Among Persons Living with HIV. J. Clin. Psychol. Med Settings 2016, 23, 126-134. [CrossRef] [PubMed]

97. Kamitani, E.; Chen, J.-L.; Portillo, C.; Tokumoto, J.; Dawson-Rose, C. Shortened and Culturally Appropriate HIV Stigma Scale for Asians Living with HIV in the United States: Psychometric Analysis. J. Assoc. Nurses AIDS Care 2018, 29, 560-569. [CrossRef]

98. Kang, E.; Delzell, D.A.P.; Mbonyingabo, C. Understanding HIV Transmission and Illness Stigma: A Relationship Revisited in Rural Rwanda. AIDS Educ. Prev. 2017, 29, 540-553. [CrossRef]

99. Kerrigan, D.; Karver, T.S.; Barrington, C.; Donastorg, Y.; Perez, M.; Gomez, H.; Mbwambo, J.; Likindikoki, S.; Davis, W.; Beckham, S.W.; et al. Mindfulness, Mental Health and HIV Outcomes Among Female Sex Workers in the Dominican Republic and Tanzania. AIDS Behav. 2021, 25, 2941-2950. [CrossRef] [PubMed]

100. Kerrigan, D.; Vazzano, A.; Bertoni, N.; Malta, M.; Bastos, F.I. Stigma, discrimination and HIV outcomes among people living with HIV in Rio de Janeiro, Brazil: The intersection of multiple social inequalities. Glob. Public Health 2017, 12, 185-199. [CrossRef] [PubMed]

101. Lacombe-Duncan, A.; Warren, L.; Kay, E.S.; Persad, Y.; Soor, J.; Kia, H.; Underhill, A.; Logie, C.H.; Kazemi, M.; Kaida, A.; et al. Mental health among transgender women living with HIV in Canada: Findings from a national community-based research study. AIDS Care 2021, 33, 192-200. [CrossRef] [PubMed]

102. Li, H.; Chen, X.; Yu, B. Disclosure appraisal mediating the association between perceived stigma and HIV disclosure to casual sex partners among HIV+ MSM: A path model analysis. AIDS Care 2016, 28, 722-725. [CrossRef]

103. Li, M.; Murray, J.K.; Suwanteerangkul, J.; Wiwatanadate, P. Stigma, Social Support, and Treatment Adherence Among HIV-Positive Patients in Chiang Mai, Thailand. AIDS Educ. Prev. 2014, 26, 471-483. [CrossRef]

104. Li, Z.; Hsieh, E.; Morano, J.P.; Sheng, Y. Exploring HIV-related stigma among HIV-infected men who have sex with men in Beijing, China: A correlation study. AIDS Care 2016, 28, 1394-1401. [CrossRef] [PubMed]

105. Li, Z.; Sheng, Y. Investigation of perceived stigma among people living with human immunodeficiency virus/acquired immune deficiency syndrome in Henan Province, China. Int. J. Nurs. Sci. 2014, 1, 385-388. [CrossRef]

106. Lin, X.; Zhao, G.; Li, X.; Stanton, B.; Zhang, L.; Hong, Y.; Zhao, J.; Fang, X. Perceived HIV stigma among children in a high HIV-prevalence area in central China: Beyond the parental HIV-related illness and death. AIDS Care 2010, 22, 545-555. [CrossRef]

107. Lindberg, M.H.; Wettergren, L.; Wiklander, M.; Svedhem-Johansson, V.; Eriksson, L.E. Psychometric Evaluation of the HIV Stigma Scale in a Swedish Context. PLoS ONE 2014, 9, e114867. [CrossRef]

108. Liu, H.; Zhao, M.; Ren, J.; Qi, X.; Sun, H.; Qu, L.; Yan, C.; Zheng, T.; Wu, Q.; Cui, Y. Identifying factors associated with depression among men living with HIV/AIDS and undergoing antiretroviral therapy: A cross-sectional study in Heilongjiang, China. Health Qual. Life Outcomes 2018, 16, 1-10. [CrossRef]

109. Liu, Y.; Gong, H.; Yang, G.; Yan, J. Perceived stigma, mental health and unsafe sexual behaviors of people living with HIV/AIDS. J. Cent. South Univ. 2014, 39, 658-663. [CrossRef]

110. Logie, C.H.; Wang, Y.; Marcus, N.; Kaida, A.; O’Brien, N.; Nicholson, V.; Webster, K.; Conway, T.; De Pokomandy, A.; Loutfy, M. Factors Associated with the Separate and Concurrent Experiences of Food and Housing Insecurity Among Women Living with HIV in Canada. AIDS Behav. 2018, 22, 3100-3110. [CrossRef]

111. Luz, P.M.; Torres, T.S.; Almeida-Brasil, C.C.; Marins, L.M.S.; Bezerra, D.R.B.; Veloso, V.G.; Grinsztejn, B.; Harel, D.; Thombs, B.D. Translation and validation of the Short HIV Stigma scale in Brazilian Portuguese. Health Qual. Life Outcomes 2020, 18, 1-12. [CrossRef]

112. Lyimo, R.A.; Stutterheim, S.E.; Hospers, H.J.; De Glee, T.; Van Der Ven, A.; De Bruin, M. Stigma, Disclosure, Coping, and Medication Adherence Among People Living with HIV/AIDS in Northern Tanzania. AIDS Patient Care STDs 2014, $28,98-105$. [CrossRef] [PubMed] 
113. Magidson, J.F.; Saal, W.; Nel, A.; Remmert, J.E.; Kagee, A. Relationship between depressive symptoms, alcohol use, and antiretroviral therapy adherence among HIV-infected, clinic-attending patients in South Africa. J. Health Psychol. 2017, 22, 1426-1433. [CrossRef]

114. Mahlomaholo, P.M.; Wang, H.; Xia, Y.; Wang, Y.; Yang, X.; Wang, Y. Depression and Suicidal Behaviors Among HIV-Infected Inmates in Lesotho: Prevalence, Associated Factors and a Moderated Mediation Model. AIDS Behav. 2021, 25, 3255-3266. [CrossRef] [PubMed]

115. Mao, Y.; Li, X.; Qiao, S.; Zhao, Q.; Zhou, Y.; Shen, Z. Social support, stigma, and HIV disclosure among parents living with HIV in Guangxi, China. AIDS Care 2018, 30, 168-172. [CrossRef]

116. Martiana, I.; Waluyo, A.; Yona, S. Assessing the relationship between knowledge of antiretroviral therapy and stigma regarding adherence to ART among men who have sex with men. Enferm. Clin. 2019, 29, 321-325. [CrossRef]

117. Martinez, J.; Harper, G.; Carleton, R.A.; Hosek, S.; Bojan, K.; Clum, G. The Impact of Stigma on Medication Adherence Among HIV-Positive Adolescent and Young Adult Females and the Moderating Effects of Coping and Satisfaction with Health Care. AIDS Patient Care STDs 2012, 26, 108-115. [CrossRef]

118. Mason, S.; Berger, B.; Ferrans, C.E.; Sultzman, V.; Fendrich, M. Developing a Measure of Stigma by Association with African American Adolescents Whose Mothers Have HIV. Res. Soc. Work Pract. 2010, 20, 65-73. [CrossRef]

119. Mi, T.; Zhou, G.; Li, X.; Qiao, S.; Yang, X.; Shen, Z.; Zhou, Y. The association between HIV disclosure to family members and quality of life among people living with HIV/AIDS: The indirect effects through social support. Curr. Psychol. 2021. [CrossRef]

120. Miller, C.T.; Grover, K.W.; Bunn, J.Y.; Solomon, S.E. Community Norms About Suppression of AIDS-Related Prejudice and Perceptions of Stigma by People with HIV or AIDS. Psychol. Sci. 2011, 22, 579-583. [CrossRef]

121. Montaño, D.; Martínez-Cajas, J.; Balfour, L.; Fabio Mueses, H.; Galindo, J.; Alvarado, B. Psychometric Properties of a Spanish Version of the 10-Item Berger's Stigma Scale in Colombia: A Validation Study: Propiedades Psicométricas De Una Versión En Español De La Escala De Berger De Diez Ítems En Colombia: Un Estudio De Validación. ARS Med. Rev. Cienc. Méd. 2020, 45, 6-15. [CrossRef]

122. Mukherjee, A.; Lahiry, S.; Mukherjee, A.; Choudhury, S.; Sinha, R. Study on Defense Mechanisms to Cope with Stress Due to Stigma Among People Living with HIV/AIDS Reported in Eastern India: A Single Center Experience. Indian J. Clin. Med. 2017, 8, 1179916117742919. [CrossRef]

123. Murphy, D.A.; Austin, E.L.; Greenwell, L. Correlates of HIV-Related Stigma Among HIV-Positive Mothers and Their Uninfected Adolescent Children. Women Health 2007, 44, 19-42. [CrossRef]

124. Murphy, P.J.; Garrido-Hernansaiz, H.; Mulcahy, F.; Hevey, D. HIV-related stigma and optimism as predictors of anxiety and depression among HIV-positive men who have sex with men in the United Kingdom and Ireland. AIDS Care 2018, 30, 1173-1179. [CrossRef]

125. Mutumba, M.; Bauermeister, J.; Harper, G.W.; Musiime, V.; Lepkowski, J.; Resnicow, K.; Snow, R.C. Psychological distress among Ugandan adolescents living with HIV: Examining stressors and the buffering role of general and religious coping strategies. Glob. Public Health 2017, 12, 1479-1491. [CrossRef]

126. Nabunya, P.; Byansi, W.; Bahar, O.S.; McKay, M.; Ssewamala, F.M.; Damulira, C. Factors Associated with HIV Disclosure and HIV-Related Stigma Among Adolescents Living with HIV in Southwestern Uganda. Front. Psychiatry 2020, 11, 772. [CrossRef] [PubMed]

127. Newman, J.E.; Edmonds, A.; Kitetele, F.; Lusiama, J.; Behets, F. Social support, perceived stigma, and quality of life among HIV-positive caregivers and adult relatives of pediatric HIV index cases in Kinshasa, Democratic Republic of Congo. Vulnerable Child. Youth Stud. 2012, 7, 237-248. [CrossRef]

128. Nobre, N.; Pereira, M.; Roine, R.P.; Sutinen, J.; Sintonen, H. HIV-Related Self-Stigma and Health-Related Quality of Life of People Living with HIV in Finland. J. Assoc. Nurses AIDS Care 2018, 29, 254-265. [CrossRef]

129. Nyongesa, M.K.; Mwangi, P.; Kinuthia, M.; Hassan, A.S.; Koot, H.M.; Cuijpers, P.; Newton, C.R.J.C.; Abubakar, A. Prevalence, risk and protective indicators of common mental disorders among young people living with HIV compared to their uninfected peers from the Kenyan coast: A cross-sectional study. BMC Psychiatry 2021, 21, 90. [CrossRef]

130. Nyongesa, M.K.; Mwangi, P.; Wanjala, S.W.; Mutua, A.M.; Koot, H.M.; Cuijpers, P.; Newton, C.R.J.C.; Abubakar, A. Correlates of health-related quality of life among adults receiving combination antiretroviral therapy in coastal Kenya. Health Qual. Life Outcomes 2020, 18, 169. [CrossRef] [PubMed]

131. Nyongesa, M.K.; Mwangi, P.; Wanjala, S.W.; Mutua, A.M.; Newton, C.R.J.C.; Abubakar, A. Prevalence and correlates of depressive symptoms among adults living with HIV in rural Kilifi, Kenya. BMC Psychiatry 2019, 19, 333. [CrossRef] [PubMed]

132. Oke, O.O.; Akinboro, A.O.; Olanrewaju, F.O.; Oke, O.A.; Omololu, A.S. Assessment of HIV-related stigma and determinants among people living with HIV/AIDS in Abeokuta, Nigeria: A cross-sectional study. SAGE Open Med. 2019, 7, 2050312119869109. [CrossRef] [PubMed]

133. Olley, B.; Adebayo, K.; Ogunde, M.; Ishola, A.; Ogar, A. Psychosocial factors predicting severity of depression among treatmentseeking HIV/AIDS patients: A multi-site Nigerian study. Niger. J. Clin. Pract. 2017, 20, 296. [CrossRef]

134. Olley, B.O.; Ogunde, M.J.; Oso, P.O.; Ishola, A. HIV-related stigma and self-disclosure: The mediating and moderating role of anticipated discrimination among people living with HIV/AIDS in Akure Nigeria. AIDS Care 2016, 28, 726-730. [CrossRef] 
135. Palar, K.; Frongillo, E.A.; Escobar, J.; Sheira, L.A.; Wilson, T.E.; Adedimeji, A.; Merenstein, D.; Cohen, M.H.; Wentz, E.L.; Adimora, A.A.; et al. Food Insecurity, Internalized Stigma, and Depressive Symptoms Among Women Living with HIV in the United States. AIDS Behav. 2018, 22, 3869-3878. [CrossRef]

136. Patel, R.; Kassaye, S.; Gore-Felton, C.; Wyshak, G.; Kadzirange, G.; Woelk, G.; Katzenstein, D. Quality of life, psychosocial health, and antiretroviral therapy among HIV-positive women in Zimbabwe. AIDS Care 2009, 21, 1517-1527. [CrossRef] [PubMed]

137. Pearson, C.R.; Micek, M.A.; Pfeiffer, J.; Montoya, P.; Matediane, E.; Jonasse, T.; Cunguara, A.; Rao, D.; Gloyd, S.S. One Year After ART Initiation: Psychosocial Factors Associated with Stigma Among HIV-Positive Mozambicans. AIDS Behav. 2009, 13, 1189-1196. [CrossRef]

138. Peltzer, K.; Babayigit, S.; Rodriguez, V.J.; Jean, J.; Sifunda, S.; Jones, D.L. Effect of a multicomponent behavioural PMTCT cluster randomised controlled trial on HIV stigma reduction among perinatal HIV positive women in Mpumalanga province, South Africa. SAHARA-J J. Soc. Asp. HIV/AIDS 2018, 15, 80-88. [CrossRef] [PubMed]

139. Porter, K.E.; Brennan-Ing, M.; Burr, J.A.; Dugan, E.; Karpiak, S.E. Stigma and Psychological Well-being Among Older Adults with HIV: The Impact of Spirituality and Integrative Health Approaches. Gerontologist 2017, 52, 219-228. [CrossRef] [PubMed]

140. Przybyla, S.M.; Golin, C.E.; Widman, L.; Grodensky, C.A.; Earp, J.A.; Suchindran, C. Serostatus disclosure to sexual partners among people living with HIV: Examining the roles of partner characteristics and stigma. AIDS Care 2013, 25, 566-572. [CrossRef] [PubMed]

141. Qin, S.; Tan, Y.; Lu, B.; Cheng, Y.; Nong, Y. Survey and analysis for impact factors of psychological distress in HIV-infected pregnant women who continue pregnancy. J. Matern. Neonatal Med. 2019, 32, 3160-3167. [CrossRef]

142. Quinn, K.; Voisin, D.R.; Bouris, A.; Jaffe, K.; Kuhns, L.; Eavou, R.; Schneider, J. Multiple Dimensions of Stigma and Health Related Factors Among Young Black Men Who Have Sex with Men. AIDS Behav. 2017, 21, 207-216. [CrossRef]

143. Rao, D.; Chen, W.-T.; Pearson, C.; Simoni, J.; Fredriksen-Goldsen, K.; Nelson, K.; Zhao, H.; Zhang, F. Social support mediates the relationship between HIV stigma and depression/quality of life among people living with HIV in Beijing, China. Int. J. STD AIDS 2012, 23, 481-484. [CrossRef]

144. Rao, D.; Pryor, J.B.; Gaddist, B.W.; Mayer, R. Stigma, Secrecy, and Discrimination: Ethnic/Racial Differences in the Concerns of People Living with HIV / AIDS. AIDS Behav. 2008, 12, 265-271. [CrossRef] [PubMed]

145. Rasoolinejad, M.; Abedinia, N.; Noorbala, A.A.; Mohraz, M.; Jozani, Z.B.; Badie, B.M. The Effect of Psycho-Social Problems on Risky Behaviors in People Living with HIV in Tehran, Iran. J. Fam. Reprod. Health 2018, 12, 89-95.

146. Reinius, M.; Rao, D.; Manhart, L.E.; Wiklander, M.; Svedhem, V.; Pryor, J.; Mayer, R.; Gaddist, B.; Kumar, S.; Mohanraj, R.; et al. Differential item functioning for items in Berger's HIV Stigma Scale: An analysis of cohorts from the Indian, Swedish, and US contexts. Qual. Life Res. 2018, 27, 1647-1659. [CrossRef]

147. Reinius, M.; Wettergren, L.; Wiklander, M.; Svedhem, V.; Ekström, A.M.; Eriksson, L.E. Development of a 12-item short version of the HIV stigma scale. Health Qual. Life Outcomes 2017, 15, 115. [CrossRef]

148. Rendina, H.J.; Golub, S.A.; Grov, C.; Parsons, J.T. Stigma and sexual compulsivity in a community-based sample of HIV-positive gay and bisexual men. AIDS Behav. 2012, 16, 741-750. [CrossRef] [PubMed]

149. Rice, W.; Crockett, K.B.; Mugavero, M.J.; Raper, J.L.; Atkins, G.C.; Turan, B. Association Between Internalized HIV-Related Stigma and HIV Care Visit Adherence. J. Acquir. Immune Defic. Syndr. 2017, 76, 482-487. [CrossRef]

150. Riggs, S.A.; Vosvick, M.; Stallings, S. Attachment Style, Stigma and Psychological Distress among HIV+ Adults. J. Health Psychol. 2007, 12, 922-936. [CrossRef]

151. Rubtsova, A.A.; Wingood, G.; Ofotokun, I.; Mehta, C.C.; Gustafson, D.; Vance, D.E.; Sharma, A.; Adimora, A.A.; Holstad, M. Psychosocial Mechanisms of Self-rated Successful Aging with HIV: A Structural Equation Model. AIDS Behav. 2021, 25, $2875-2885$. [CrossRef]

152. Rueda, S.; the OHTN Cohort Study Team; Gibson, K.; Rourke, S.B.; Bekele, T.; Gardner, S.; Cairney, J. Mastery Moderates the Negative Effect of Stigma on Depressive Symptoms in People Living with HIV. AIDS Behav. 2012, 16, 690-699. [CrossRef]

153. Schensul, S.L.; Ha, T.; Schensul, J.J.; Grady, J.; Burleson, J.A.; Gaikwad, S.; Joshi, K.; Malye, R.; Sarna, A. Multilevel and Multifactorial Interventions to Reduce Alcohol Consumption and Improve ART Adherence and Related Factors Among HIV Positive Men in Mumbai, India. AIDS Behav. 2021, 25, 290-301. [CrossRef]

154. Seb-Akahomen, O.J.; Lawani, A.O.; James, B.O. Stigma and suicidality among people living with HIV attending a secondary healthcare facility in Nigeria. Perspect. Psychiatr. Care 2019, 55, 538-545. [CrossRef] [PubMed]

155. Seghatol-Eslami, V.C.; Dark, H.E.; Raper, J.L.; Mugavero, M.J.; Turan, J.M.; Turan, B. Brief Report: Interpersonal and Intrapersonal Factors as Parallel Independent Mediators in the Association Between Internalized HIV Stigma and ART Adherence. J. Acquir. Immune Defic. Syndr. 2017, 74, e18-e22. [CrossRef]

156. Sereda, Y.; Kiriazova, T.; Makarenko, O.; Carroll, J.J.; Rybak, N.; Chybisov, A.; Bendiks, S.; Idrisov, B.; Dutta, A.; Gillani, F.S.; et al. Stigma and quality of co-located care for HIV-positive people in addiction treatment in Ukraine: A cross-sectional study. J. Int. AIDS Soc. 2020, 23, e25492. [CrossRef]

157. Shamsaei, F.; Tahour, N.; Sadeghian, E. Effect of Stress Management Training on Stigma and Social Phobia in HIV-Positive Women. J. Int. Assoc. Provid. AIDS Care 2020, 19, 2325958220918953. [CrossRef]

158. Shokoohi, M.; Bauer, G.R.; Kaida, A.; Logie, C.H.; Lacombe-Duncan, A.; Milloy, M.; Lloyd-Smith, E.; Carter, A.; Loutfy, M.; on behalf of the CHIWOS Research Team. Patterns of social determinants of health associated with drug use among women living with HIV in Canada: A latent class analysis. Addiction 2019, 114, 1214-1224. [CrossRef] [PubMed] 
159. Shrestha, R.; Copenhaver, M.; Bazazi, A.R.; Huedo-Medina, T.B.; Krishnan, A.; Altice, F. A Moderated Mediation Model of HIV-Related Stigma, Depression, and Social Support on Health-Related Quality of Life among Incarcerated Malaysian Men with HIV and Opioid Dependence. AIDS Behav. 2017, 21, 1059-1069. [CrossRef]

160. Song, B.; Yan, C.; Lin, Y.; Wang, F.; Wang, L. Health-Related Quality of Life in HIV-Infected Men Who Have Sex with Men in China: A Cross-Sectional Study. Med. Sci. Monit. 2016, 22, 2859-2870. [CrossRef]

161. Storholm, E.D.; Halkitis, P.N.; Kupprat, S.A.; Hampton, M.C.; Palamar, J.J.; Brennan-Ing, M.; Karpiak, S. HIV-Related Stigma as a Mediator of the Relation Between Multiple-Minority Status and Mental Health Burden in an Aging HIV-Positive Population. J. HIV/AIDS Soc. Serv. 2013, 12, 9-25. [CrossRef]

162. Boer, I.M.S.-D.; Nellen, J.F.B.; Sprangers, M.A.G.; Prins, J.M.; Nieuwkerk, P.T. Personalized Stigma and Disclosure Concerns Among HIV-Infected Immigrant and Indigenous HIV-Infected Persons in the Netherlands. J. HIV/AIDS Soc. Serv. 2012, 11, 42-56. [CrossRef]

163. Tanney, M.R.; Naar-King, S.; MacDonnel, K. Depression and Stigma in High-Risk Youth Living with HIV: A Multi-Site Study. J. Pediatr. Health Care 2012, 26, 300-305. [CrossRef] [PubMed]

164. Thomas, B.E.; Rehman, F.; Suryanarayanan, D.; Josephine, K.; Dilip, M.; Dorairaj, V.S.; Swaminathan, S. How stigmatizing is Stigma in the life of people living with HIV: A study on HIV positive individuals from Chennai, South India. AIDS Care 2005, 17, 795-801. [CrossRef] [PubMed]

165. Tomassilli, J.C.; Parsons, J.T.; Golub, S.A. What's Sex Got to Do with It? The Role of Sexual Affect in the Relationship Between HIV Stigma and Mental Health. AIDS Behav. 2013, 17, 1770-1774. [CrossRef] [PubMed]

166. Toth, S.; York, J.A.; DePinto, N. HIV stigma: Perceptions from HIV-positive and HIV-negative patients in a community dental clinic. J. Dent. Res. Dent. Clin. Dent. Prospect. 2016, 10, 263-269. [CrossRef]

167. Turan, B.; Budhwani, H.; Fazeli, P.L.; Browning, W.R.; Raper, J.L.; Mugavero, M.J.; Turan, J.M. How Does Stigma Affect People Living with HIV? The Mediating Roles of Internalized and Anticipated HIV Stigma in the Effects of Perceived Community Stigma on Health and Psychosocial Outcomes. AIDS Behav. 2017, 21, 283-291. [CrossRef]

168. Turan, B.; Rogers, A.J.; Rice, W.S.; Atkins, G.C.; Cohen, M.H.; Wilson, T.E.; Adimora, A.A.; Merenstein, D.; Adedimeji, A.; Wentz, E.L.; et al. Association between Perceived Discrimination in Healthcare Settings and HIV Medication Adherence: Mediating Psychosocial Mechanisms. AIDS Behav. 2017, 21, 3431-3439. [CrossRef] [PubMed]

169. Turan, B.; Smith, W.; Cohen, M.H.; Wilson, T.E.; Adimora, A.A.; Merenstein, D.; Adedimeji, A.; Wentz, E.L.; Foster, A.G.; Metsch, L.; et al. Mechanisms for the Negative Effects of Internalized HIV-Related Stigma on Antiretroviral Therapy Adherence in Women. J. Acquir. Immune Defic. Syndr. 2016, 72, 198-205. [CrossRef]

170. Valenzuela, C.; Ugarte-Gil, C.; Paz, J.; Echevarria, J.; Gotuzzo, E.; Vermund, S.; Kipp, A.M. HIV Stigma as a Barrier to Retention in HIV Care at a General Hospital in Lima, Peru: A Case-Control Study. AIDS Behav. 2015, 19, 235-245. [CrossRef]

171. Valle, A.; Treviño, A.C.; Zambrano, F.F.; Urriola, K.E.; Sanchez, L.A.; Elizondo, J.E. Perceived HIV-Associated Stigma among HIV-Seropositive Men: Psychometric Study of HIV Stigma Scale. Front. Public Health 2015, 3, 171. [CrossRef]

172. Van der Kooij, Y.L.; Kupková, A.; Daas, C.D.; Berk, G.E.V.D.; Kleene, M.J.T.; Jansen, H.S.; Elsenburg, L.J.; Schenk, L.G.; Verboon, P.; Brinkman, K.; et al. Role of Self-Stigma in Pathways from HIV-Related Stigma to Quality of Life Among People Living with HIV. AIDS Patient Care STDs 2021, 35, 231-238. [CrossRef] [PubMed]

173. Varni, S.E.; Miller, C.T.; McCuin, T.; Solomon, S.; Richardson, S. Disengagement and Engagement Coping with HIV/AIDS Stigma and Psychological Well-Being of People with HIV / AIDS. J. Soc. Clin. Psychol. 2012, 31, 123-150. [CrossRef]

174. Voisin, D.R.; Quinn, K.; Kim, D.H.; Schneider, J. A Longitudinal Analysis of Antiretroviral Adherence Among Young Black Men Who Have Sex with Men. J. Adolesc. Health 2017, 60, 411-416. [CrossRef]

175. Wang, W.; Yang, N.; Li, X.; Xiao, H.; Gao, M.; Yan, H.; Li, S. A pathway analysis of exploring how HIV-related stigma affects social capital among people living with HIV/AIDS in China. Psychol. Health Med. 2019, 24, 1100-1110. [CrossRef] [PubMed]

176. Williams, R.; Cook, R.; Brumback, B.; Cook, C.; Ezenwa, M.; Spencer, E.; Lucero, R. The relationship between individual characteristics and HIV-related stigma in adults living with HIV: Medical monitoring project, Florida, 2015-2016. BMC Public Health 2020, 20, 723. [CrossRef]

177. Wolitski, R.J.; Pals, S.L.; Kidder, D.P.; Courtenay-Quirk, C.; Holtgrave, D. The Effects of HIV Stigma on Health, Disclosure of HIV Status, and Risk Behavior of Homeless and Unstably Housed Persons Living with HIV. AIDS Behav. 2009, 13, 1222-1232. [CrossRef] [PubMed]

178. Wright, K.; Naar-King, S.; Lam, P.; Templin, T.; Frey, M. Stigma Scale Revised: Reliability and Validity of a Brief Measure of Stigma for HIV+ Youth. J. Adolesc. Health 2007, 40, 96-98. [CrossRef] [PubMed]

179. Wu, D.Y.; Munoz, M.; Espiritu, B.; Zeladita, J.; Sanchez, E.; Callacna, M.; Rojas, C.; Arevalo, J.; Caldas, A.; Shin, S. Burden of Depression Among Impoverished HIV-Positive Women in Peru. J. Acquir. Immune Defic. Syndr. 2008, 48, 500-504. [CrossRef] [PubMed]

180. Xiao, Z.; Li, X.; Qiao, S.; Zhou, Y.; Shen, Z.; Tang, Z. Using communication privacy management theory to examine HIV disclosure to sexual partners/spouses among PLHIV in Guangxi. AIDS Care 2015, 27, 73-82. [CrossRef] [PubMed]

181. Yang, H.; Xie, X.; Nie, A.; Yin, Y.; Wang, H.; Chen, H. HIV-Related Stigma Among People Living with HIV in Liangshan Yi Autonomous Prefecture, China. J. Assoc. Nurses AIDS Care 2020, 31, 199-207. [CrossRef] [PubMed]

182. Yang, X.; Li, X.; Qiao, S.; Li, L.; Parker, C.; Shen, Z.; Zhou, Y. Intersectional stigma and psychosocial well-being among MSM living with HIV in Guangxi, China. AIDS Care 2020, 32, 5-13. [CrossRef] [PubMed] 
183. Yigit, I.; Bayramoglu, Y.; Weiser, S.D.; Johnson, M.O.; Mugavero, M.J.; Turan, J.M.; Turan, B. Changes in Internalized Stigma and HIV Health Outcomes in Individuals New to HIV Care: The Mediating Roles of Depression and Treatment Self-Efficacy. AIDS Patient Care STDs 2020, 34, 491-497. [CrossRef]

184. Yu, C.; Huang, C.; Lee, Y.; Cheng, S. Development of an 18-item abbreviated Chinese version of Berger's HIV Stigma Scale. Int. J. Nurs. Pract. 2019, 25, e12708. [CrossRef]

185. Zeligman, M.; Barden, S.M.; Hagedorn, W.B. Posttraumatic Growth and HIV: A Study on Associations of Stigma and Social Support. J. Couns. Dev. 2016, 94, 141-149. [CrossRef]

186. Zeng, C.; Li, L.; Hong, Y.A.; Zhang, H.; Babbitt, A.W.; Liu, C.; Li, L.; Qiao, J.; Guo, Y.; Cai, W. A structural equation model of perceived and internalized stigma, depression, and suicidal status among people living with HIV/AIDS. BMC Public Health 2018, 18, 138. [CrossRef] [PubMed]

187. Zhang, C.; Li, X.; Liu, Y.; Qiao, S.; Zhang, L.; Zhou, Y.; Shen, Z.; Tang, Z. Emotional, physical and financial burdens of stigma against people living with HIV/AIDS in China. AIDS Care 2016, 28, 124-131. [CrossRef]

188. Zhang, L.; Li, X.; Qiao, S.; Zhou, Y.; Shen, Z.; Tang, Z.; Shah, I.H.; Stanton, B. The mediating role of individual resilience resources in stigma-health relationship among people living with HIV in Guangxi, China. AIDS Care 2015, 27, 1317-1325. [CrossRef] [PubMed]

189. Zhou, G.; Li, X.; Qiao, S.; Zhou, Y.; Shen, Z. Psychological and behavioral barriers to ART adherence among PLWH in China: Role of self-efficacy. AIDS Care 2017, 29, 1533-1537. [CrossRef]

190. Zulliger, R.; Barrington, C.; Donastorg, Y.; Perez, M.; Kerrigan, D. High Drop-off Along the HIV Care Continuum and ART Interruption Among Female Sex Workers in the Dominican Republic. J. Acquir. Immune Defic. Syndr. 2015, 69, 216-222. [CrossRef] [PubMed]

191. Cicchetti, D.V. Guidelines, Criteria, and Rules of Thumb for Evaluating Normed and Standardized Assessment Instruments in Psychology. Psychol. Assess. 1994, 6, 284-290. [CrossRef]

192. Too, E.K.; Abubakar, A.; Nasambu, C.; Koot, H.M.; Cuijpers, P.; Newton, C.R.; Nyongesa, M.K. Prevalence and factors associated with common mental disorders in young people living with HIV in sub-Saharan Africa: A systematic review. J. Int. AIDS Soc. 2021, 24, e25705. [CrossRef]

193. Baggaley, R.; Armstrong, A.; Dodd, Z.; Ngoksin, E.; Krug, A. Young key populations and HIV: A special emphasis and consideration in the new WHO Consolidated Guidelines on HIV Prevention, Diagnosis, Treatment and Care for Key Populations. J. Int. AIDS Soc. 2015, 18, 19438. [CrossRef]

194. Dellar, R.C.; Dlamini, S.; Karim, Q.A. Adolescent girls and young women: Key populations for HIV epidemic control. J. Int. AIDS Soc. 2015, 18, 19408. [CrossRef] [PubMed]

195. Rueda, S.; Mitra, S.; Chen, S.; Gogolishvili, D.; Globerman, J.; Chambers, L.; Wilson, M.; Logie, C.H.; Shi, Q.; Morassaei, S.; et al. Examining the associations between HIV-related stigma and health outcomes in people living with HIV/AIDS: A series of meta-analyses. BMJ Open 2016, 6, e011453. [CrossRef] [PubMed]

196. Zaiţ, A.; Bertea, P. Methods for Testing Discriminant Validity. Manag. Mark. J. 2011, 9, 217-224.

197. Reidpath, D.D.; Allotey, P. The problem of 'trickle-down science' from the Global North to the Global South. BMJ Glob. Health 2019, 4, e001719. [CrossRef] 